\title{
ORGANIZATIONAL GOVERNANCE
}

\author{
Nicolai J. Foss \\ Center for Strategic Management and Globalization \\ Copenhagen Business School \\ Porcelainshaven 24; 2000 Frederiksberg; Denmark \\ njf.smg@cbs.dk \\ Peter G. Klein \\ Contracting and Organizations Research Institute \\ University of Missouri \\ 135 Mumford Hall; Columbia, MO 65211 USA \\ pklein@missouri.edu
}

\section{Revised version: 8 June 2008}

Word Count: 30,067 (total text); 22,564 (main body)

Prepared for Raphael Wittek, Tom Snijders, and Victor Nee, eds.

The Handbook of Rational Choice Social Research.

New York: Russell Sage Foundation, 2008.

\section{ACKNOWLEDGMENTS:}

We thank (without implicating) Teppo Felin and Anna Grandori for discussion of issues treated in this chapter and for comments on earlier versions.

\section{KEYWORDS:}

Rational choice, organizational economics, governance structures, governance mechanisms. 


\title{
ORGANIZATIONAL GOVERNANCE
}

\begin{abstract}
This chapter reviews and discusses rational-choice approaches to organizational governance.

These approaches are found primarily in organizational economics (virtually no rational-choice organizational sociology exists), particularly in transaction cost economics, principal-agent theory, and the incomplete-contracts or property-rights approach. We distill the main unifying characteristics of these streams, survey each stream, and offer some critical commentary and suggestions for moving forward.
\end{abstract}




\section{CONTENTS}

\section{Introduction}

Organizational Governance from a Rational-Choice Perspective: a Primer

Organizations

Governance Structures and Governance Mechanisms

Why Does Organizational Governance Emerge?

An Example

Problems of Organizational Governance

Overall Characteristics of Rational-Choice Approaches to Organizational Governance

\section{A Closer Look at Rational-Choice Approaches to Organizational Governance}

The Firm in Economics: Changing Conceptions

Coase and Beyond

Analytical Advances as Driving Organizational Economics

Research Streams in Organizational Economics

The Nexus of Contracts View

Formal Agency Theory

Incomplete Contracts: The Coordination Perspective

Incomplete Contracts: Williamson's TCE and (New) Property Rights Perspectives

Extensions

Syntheses

Applications and Evidence

Organizational Boundaries

The Internal Structure of the Firm

Mergers and Acquisitions and Diversification

Antitrust and Regulation

Public Bureaucracies

\section{Critiques}

Cognition

Motivation

Neglect of Entrepreneurship

Process Issues

Reflexivity

Organizational Sociology

\section{Conclusions}




\section{INTRODUCTION: ORGANIZATIONAL GOVERNANCE}

As Herbert Simon (1991: 27) noted, a mythical Martian, equipped with a telescope that reveals social structures and approaching the earth from space, would recognize organizations, rather than connecting markets, as "the dominant feature of the landscape." And yet, Simon noted, organizations and organizational governance have been offered comparatively little attention by social scientists. Things have certainly improved since Simon wrote; in particular, rational-choice approaches to organizations, particularly in economics, have become large and influential bodies of research. Such approaches seek to examine the wide variety of organizational forms we observe and to explain them in terms of economic efficiency, throwing light on issues like outsourcing, offshoring, downsizing, new organizational forms, and the increased use high-powered performance, besides the more traditional issues of the existence and boundaries of the firm (Coase, 1937). This chapter surveys and discusses rational-choice approaches to these aspects of organizational governance.

It is useful to begin by clarifying the subject of the chapter because the term "organizational governance," while accurate, does not enjoy particularly widespread use. As a first approximation, organizational governance refers to the instruments of governance that organizations deploy to influence organization members and other stakeholders to contribute to organizational goals. This understanding is clearly consistent with the more frequently used terms "organizational control" and "governance structures and mechanisms." As traditionally understood, these refer to mechanisms inside and between organizations that may influence behaviors in desired directions (Scott, 1992; Williamson, 1996). Strictly speaking "organizational governance" is not a distinct field but a set of (partly overlapping) fields and sub-fields of "organization theory," "organizational studies," "organizational sociology," "organizational behavior," "organizational economics," "the theory of the firm" and "corporate governance" that more or less eclectically draw on the base disciplines of economics, sociology, psychology, political science, industrial engineering, and others. Organizational governance as defined above relates to and partly overlaps with all of these fields.

Of course, adopting a rational-choice perspective (Coleman, 1990; Abell, 1991; Sugden, 1991) reduces the scope of organizational governance considerably. Large parts of organizational studies and organizational behavior fall outside such a perspective. Indeed, the practice of contrasting "rational" perspectives on organizations and rational-choice approaches to action and 
behavior with alternative approaches have long been standard rhetorical practices within the field of organization studies (e.g., March and Simon, 1958; Scott, 1992). A rational-choice perspective on organizational governance suggests the following understanding of organizational governance:

Organizational governance concerns how agents, pursuing their own interests, and with different preferences, knowledge or information, and endowments, use instruments of control to regulate their transactions to avoid problems of coordination and motivation they confront when interacting within or through the purposefully designed social systems known as "organizations."

"Instruments of control" should be understood in a general sense, including both "hard" (managerial authority and formal incentive systems) and "soft" (culture, psychological contracts, framing) means of controlling and influencing agents. Behavior, and therefore ultimately organizational outcomes, may be influenced through influencing the motivations, beliefs, preferences, and information of organizational members. Note that the hard and soft approaches to some extent reflect the different approaches of economics and sociology, respectively. Economists have dealt largely with hard governance, placing soft governance under the abstract heading of "implicit contracts," while (organizational) sociologists have sought to treat both aspects of organizational governance (Weber, 1947; see also Bradach and Eccles, 1989), though recently soft or "informal" governance has gotten the most attention (Nooteboom and Six, 2003).

The above is obviously a highly abstract definition; an unpacking will be undertaken later. However, note for the moment that the definition involves a notion of rational design (undertaken to reach preferred outcomes), takes individual agents as the relevant decision-makers (rather than "the organization"), conceptualizes these agents as sufficiently clever to recognize the interaction problems they may face, and (implicitly) frames these problems in game-theoretic terms. These features are key to the rational-choice approach. In terms of the phenomenon, organizational governance includes but is broader than the notion of "organizational control." The latter notion mainly refers to the governance of human capital inputs inside an organization (and sometimes only with the monitoring and evaluation of human capital services), and implies a notion of the corporate person of the firm as the principal and human capital owners as agents. The notion of organizational governance is broader in that it includes a broader set of stakeholders, such as owners of capital and input suppliers. 
A concern with how control may be exercised by organizations and managers has a considerably longer history in sociology than in economics. Although early economics contributions-particularly Knight (1921) and Coase (1937)—were contemporaneous with the emerging interest in sociology in this issue (e.g., Roethlisberger and Dickson, 1939), the economics treatments were more highly abstract and entirely theoretical. More importantly, the pioneering contributions of Knight and Coase were only recognized as seminal several decades after they were published. In contrast, organizational sociology coalesced in the 1950s (Scott, 2004), at a time when few economists took an interest in organizations (but see Simon, 1951; Downs, 1957), and about two decades before the sustained attempt to apply the tools of economics to the study of organizations. Important early contributions were made by Selznick (1949), Crozier (1963), and later influential work is represented by Pfeffer and Salancik (1978), but most of this has remained fairly resistant to rational-choice approaches (perhaps except for Crozier and his followers). In fact, organizational sociologists have often been very strongly critical (e.g., Perrow, 1986, 2002; but see, e.g., Scott [1995], Nooteboom and Six [2003) and Buskens, Raub and Snijders [2003] for more conciliatory approaches). There is little rational-choice sociology literature that deals with organizational governance, ${ }^{1}$ and also little relevant political science literature (but see Hammond and Miller, 1985; Miller, 1992). The part of "rational" organizational theory approaches (Scott, 1992) that is often called the Carnegie school (March and Simon, 1958; Cyert and March, 1963) largely emerged from a friendly and immanent critique of the rational-choice model. While this may not be rational-choice theory proper, it is sufficiently close, and did inspire some important rational-choice work (Williamson, 1996: Chpt. 1) to warrant commentary and reference throughout this chapter. However, the fact remains that the main manifestation of a rational-choice approach to organizational governance is organizational economics, and the chapter focuses mainly on this research stream.

The design of the chapter is as follows. We begin by providing a brief primer on organizational governance as conceptualized from a rational-choice perspective. The focus is on the key features that are shared by rational-choice approaches. These are illustrated by means of a simple game theoretical example. We then provide a more detailed overview and discussion of the various currents in the field, largely organized chronologically and around the main contributions to

\footnotetext{
${ }^{1}$ However, some parts of Lawler's work come close (e.g., Lawler, 2002). Siegwart Lindenberg's work (e..g, Lindenberg (2003) may also be invoked, although Lindenberg's rational-choice model is one that takes into account framing and other psychological effects often disregarded in "pure" rational-choice work.
} 
the various streams. We end by discussing empirical evidence as well as various critiques and the relation to more organizational sociology.

An important proviso must finally be mentioned: The following primarily deals with organizations that are designed for a commercial purpose, first, because the largest part of the existing, relevant work deals with such organizations, and, second, because these organizations are simpler to deal with as their objective function is (in principle, at least) simpler. However, mention will be made of rational choice on government bureaucracies.

\section{ORGANIZATIONAL GOVERNANCE FROM A RATIONAL-CHOICE PERSPECTIVE: A PRIMER}

\section{Organizations}

In their classic Organizations March and Simon (1958) broadly define organizations as systems of coordinated action among individuals who differ in the dimensions of interests, preferences, and knowledge. Many writers have echoed this understanding (e.g., Arrow, 1974; Mintzberg, 1979). However, a problem with the definition is that it would seem to include what Hayek (1973) calls "spontaneous orders," that is, those orderly structures and states that are the unintended results of the interaction of intentional individuals. For example, a competitive equilibrium is indeed a pattern of coordinated action among agents who differ in the said dimensions, where the actions taken, and therefore the resulting allocation is a result of the specific institutions ("systems") under which trade takes place. At some level, this may perhaps be called an "organization," and indeed economics work on mechanism design would seem to bring such allocations within the orbit of conscious design (Hurwicz, 1973; Arrow, 1974). However, the allocation that results is, strictly speaking, an unintended consequence of intentional actions $(\mathrm{Bu}-$ chanan, 1979; Coleman, 1991).

Relatedly, it is customary (and enlightening) to make a distinction between "organizations" and "institutions" (Coase, 1937; Hayek, 1973; North, 1990; Coleman 1991; Williamson, 1996; Scott, 1995). The former are purposively constructed for specific ends and on the basis of specific rules ("made orders," in Hayek's [1973] terminology), whereas the latter may be emergent, are based on abstract rules, and are not constructed for specific purposes ("spontaneous orders") (Hayek, 1973; Coleman, 1991). The subjects of this chapter are organizations in the former sense, particularly those that are constructed for a commercial purpose, that is, firms. 
Rational-choice approaches to organizational governance share a strong design ambition with a number of approaches in organization theory (notably contingency theory). Many of the root sources of modern formal work in this vein - notably implementation theory and mechanism design theory (Guesnerie, 1992.) — are thus fundamentally design-oriented analytical enterprises (cf. also Bowles, 2004). Design approaches in organization studies have often been criticized for focusing all the attention on formal organization to the neglect of (the potentially far more important) informal organization, a critique going back to the Hawthorne experiments (Roethlisberger and Dickson, 1939; Gillespie, 1991) and Barnard (1938). Although the preoccupation in rational-choice work on organizational governance with property rights, ownership, contracts, incentives, etc. may seem to reflect a similar bias, this is in fact hardly the case. Thus, scholars in the field have been busy studying power (Rajan and Zingales, 1998), leadership (Hermalin, 1998; Jones and Olken, 2005; Majumdar and Mukand, 2007), attempts at influencing hierarchical superiors (Milgrom and Roberts, 1988a), informal authority (Aghion and Tirole, 1997), corporate culture (Jones, 1983; Kreps, 1990; Cremer, 1990), and psychological contracts (Foss, 2003; Foss, Foss and Vasquez, 2006). The underlying conjecture is that such "soft" phenomena can be studied using exactly the same methods, tools, and fundamental conceptualization of agents that are applied to the study of the "harder," more formal aspects of organization, in contrast to scholars in organization studies who, for example, often stress the need for invoking "multiple rationalities" (e.g., Dyck, 1997).

However, it should be noted that the organization/institution distinction is somewhat vague. Note that there are cases that are not easy to classify, such as firm networks that mix the planned and the emergent and where governing rules are partly abstract and partly specific. More generally, the organization/institution distinction should be thought of as end points of a spectrum. Thus, many organizations, particularly large ones, embody elements of the spontaneous order. Fundamentally, they do so, because large firms, like whole economies, embody a fundamental division of knowledge that makes an efficient centralization of dispersed knowledge in the hands of a centralizing authority prohibitively costly, and perhaps even impossible, given the tacit nature of much relevant knowledge (Foss, 1999). Such organizations must provide rules - and often rather abstract one as in the case of corporate cultures (Kreps, 1990) - in the expectation that beneficial, but partly unforeseen outcomes will result (Hayek, 1973). Moreover, there are cases in which elements of hierarchy, such as extensive information exchange and authority-like rela- 
tions, are clearly prevalent in market relations, as in the case of franchising (see further, Imai and Itami, 1985; Langlois, 1995).

\section{Governance Structures and Governance Mechanisms}

In his extremely influential version of transaction cost economics, Williamson $(1985,1996)$ argues that organizational governance is a specific form of "governance structure," namely the one that he terms "hierarchy." Williamson argues that governance structures can be classified in the categories of either the market, the hybrid or the. ${ }^{2}$ These categories exhaust all possible governance structures without remainder. Williamson defines governance structures as mechanisms for (mainly) settling ex post (i.e., after contract agreement) disputes, and predicts that forwardlooking agents will adopt the governance structures that is best suited to handle the transaction(s) they carry out between them. Thus, contractual relations are embedded in governance structures. Borrowing from Simon's (1962) discussion of marginal analysis versus comparative analysis of systems, and perhaps also borrowing from the traditional emphasis in design oriented organization theory (Lawrence and Lorsch, 1967; Galbraith, 1974) on complementarities between organizational elements, Williamson thinks of such structures as four tuples, consisting of the "attributes" of incentive intensity, administrative controls, how adaptation to external change is handled (i.e., whether in an "autonomous" or a "coordinated" manner), and contract law. These attributes are "governance mechanisms," that is, the mechanisms within a governance structures that actually coordinates activities and aligns interests. While governance structures can vary within a category - thus, the hierarchy structure encompasses the M-form, the U-form, matrix forms and much else - it still remains that the hierarchy, in contrast to the market, makes use of its own contract law (what Williamson calls "forbearance"), deploys (relatively) low-powered incentives, adapts to disturbances in a coordinated manner, and can deploy a rich administrative machinery (Williamson, 1996: Chpt. 4).

The of a strong complementary between such attributes has been subjected to a forceful critique by Grandori $(1997,2001)$ who argues that the set of coordination mechanisms is larger than portrayed by Williamson (it also encompasses voting, teaming, negotiation and norms and rules) and that Williamson grossly exaggerates complementarities between such mechanisms. She presents theoretical arguments as well as empirical arguments that governance structures are

\footnotetext{
${ }^{2}$ Williamson's notion may not be entirely fortunate for those firms that are largely non-hierarchical, namely partnerships.
} 
much less discrete than portrayed by Williamson. Rather than explaining the existence/emergence of particular discrete governance structures, Grandori rather sees the explanatory problem as one of explaining why particular governance mechanisms are bundled in specific ways to handle specific transactions and activities. Thus, she is more interested in the "microorganization" of specific governance mechanisms than the more macro issue of governance structures.

These positions are summarized here in order to indicate that the problem of "explaining organizational governance" is far from being unambiguous. What exactly is the explanandum is author-dependent as well as dependent on belonging to specific sub-fields within organizational economics. Thus, initial/pioneering work in organizational economics saw the task as one of explaining the emergence of the employment contract in a market economy (Coase, 1937; Simon, 1951), that is, essentially one governance mechanism (authority) and its contractual (and perhaps legal, cf. Coase, 1937) underpinning. Williamson's work shifted the focus to governance structures, changing the explanatory task to not only explaining the efficiency rationales of specific governance mechanisms but also why they are clustered in discrete governance structures, and much work in contract economics has, following Milgrom and Roberts (1990) and Holmström and Milgrom (1994), taken a similar approach, stressing the notion of (Edgeworth) complementarities (Weiss, 2007). The highly influential property rights approach associated with Hart and Moore in particular (Grossman and Hart, 1986; Hart and Moore, 1990) brought back simplicity in the sense that the analytical effort was concentrated on explaining the allocation of ownership rights (and therefore authority), and sidestepping the issue of governance structures as discrete bundles of interlocking governance mechanisms. Finally, some writers, notably Grandori (1997), has emphasized explaining the rationales of the specific mechanisms that may make up a particular instance of organizational governance, and giving pretensions of strong complementarities between such elements.

\section{Why Does Organizational Governance Emerge?}

James Coleman $(1990,1991)$ argues that firms exist for the same reason that money does: They reduce the problem of the "double coincidence of wants." Thus, Coleman adopts the counterfactual approach characteristic of rational-choice approaches to organizational governance: Organizational governance exists because markets "fail" (transactions are very costly to carry out) and governing transactions inside organizations is superior to market contracting (both are 
necessary conditions). However, while Coleman may identify a possible benefit of organizations, this benefit is neither a necessary nor a sufficient condition for the existence of organized entities. Specifically, Coleman does not provide a reason why such benefits cannot be realized through (possibly sophisticated) market contracting. Indeed, if there are no frictions to market contracting, there are no reasons why markets should not be capable of doing exactly this. The inference that monetary theorists have drawn from such reasoning is that a medium of exchange exists because of "transaction costs" (Starr, 2003.). Organizational economists have made a similar inference.

While the set of rational-choice approaches to organizational governance contains heterogeneous elements, all approaches may be at least reconstructed as beginning from the premise that it is necessary to throw some analytical monkey wrenches into the machinery of the perfectly competitive model (of Debreu, 1959) to explain the raison d'etre of organizational governance. This clearly unites all economics approaches, from Knight (1921) (where the argument is set particularly clearly out), over Coase (1937) and his transaction cost successors (Williamson, 1996) to modern contract theory (Salanié, 1997; Laffont and Martimort, 2002). While the relevant frictions come in many forms, from (genuine) uncertainty (Knight, 1921), imperfect foresight/bounded rationality (Coase, 1937; Kreps, 1996; MacLeod, 2002), small numbers bargaining (Williamson, 1996), haggling costs (Coase, 1937), private information (Holmström, 1979), cost of processing information (Marschak and Radner, 1972; Aoki, 1986; Bolton and Dewatripont, 1994) or inspecting quality (Barzel, 1982, 1997), imperfect legal enforcement (Hart, 1995; Williamson, 1996) etc., what is common to them all is that they make contracting imperfect relative to the full complete contingent contracting model (Debreu, 1959).

The consequence of imperfect contracting is, usually, that created value ("welfare," "wealth") falls short of the maximum that is imaginable. Thus, a first-best situation is taken as a benchmark The typical benchmark invoked by rational-choice scholars working on organizational governance is - in spite of the heavy methodological critiques of, for example, Demsetz (1969) against this "Nirvana approach" - the value creation that would have obtained if agents had been interacting in an entirely friction-less setting. Such settings may be represented by the conditions underlying the Coase theorem (Coase, 1960) or the first theorem of welfare economics (Debreu, 1959). Under these conditions maximum value creation obtains; thus, it is not possible to rearrange resource uses, coalitions, etc. so that more economic value is produced. A nota- 
ble feature of these situations is that they are, to a large extent, institutionally and organizationally neutral, in the sense that unconstrained market competition based on privately held property rights will implement the optimal allocation — as will full scale socialism. By a similar token, whether resources are primarily allocated by firms or by markets does not, strictly speaking, matter for allocational outcomes. ${ }^{3}$

Of course, such first-best efficiency conditions never obtain in actuality, and institutions and allocations are therefore not neutral in allocational terms. (The connotation to the theory of market failure should be obvious). Moreover, different institutions and organizations, embodying different mechanisms for governing inputs, typically have different allocational consequences, depending on the specifics of the situation (i.e., what is assumed about transactions, property rights, informational conditions, etc.). Indeed, a key heuristic that underlies all rational-choice approaches to organizational governance is that of matching the relevant unit of analysis (whether this is a transaction, an activity, or an input) can be assigned to a member of the set of organizational alternatives (whether governance structure or a governance mechanism) on the basis of some efficiency criterion, what Williamson (1985) calls “discriminating alignment." It is typically forwarded, often in an "as if" manner, that rational agents are efficiency seeking agents, and that changing a situation with inefficient alignment of, for example, transactions and governance structures to one with efficient alignment will create so much extra transferable utility that potential losers from the change can be compensated (e.g., Milgrom and Roberts, 1992). If transaction costs are such that efficiency-improving changes cannot be made, inefficient organizational choices may instead be weeded out by other forces, notably selection forces (Williamson, 1985).

Note in passing that it is, of course, such matching processes that give explanatory and predictive content to rational-choice approaches to organizations. To be sure, discriminating alignment is not a feature of these approaches alone. Organizational sociologists and management scholars working on organization theory, notably those working from a "contingency" or "information processing perspective" (Lawrence and Lorsch, 1967; Thompson, 1967; Galbraith, 1974) have stressed notions of "fit," typically of organizational structures and environmental conditions. However, these approaches only implicitly make use of efficiency as the criterion of

\footnotetext{
${ }^{3}$ Nevertheless, it is usually argued that with perfect and costless contracting, it is hard to see room for anything resembling organizations. In fact, it is held that even one-person firms would not exist under such conditions, since consumers could contract directly with owners of factors services and would not need the services of the intermediaries (i.e., firms) (e.g., Cheung, 1983).
} 
discrimination, are macro (organization-level), and seldom spend much time on characterizing agents in cognitive and motivational terms. ${ }^{4}$

The argument that organizational governance arises when markets fail for certain transactions or activities and organizations are superior means of governing these transactions or activities does not in itself inform us about the involved mechanisms, and without specification of such mechanisms borders on the tautological. Obviously, scholars have spent much energy on identifying and theorizing the relevant mechanisms. The Leitmotiv of the relevant work over the last three decades has been that of incentive conflicts emerging from prisoners' dilemma-like situations. Some rational-choice work in the field of organizations have taken a team theoretical starting point (Marschak and Radner, 1972; Aoki, 1986; Radner, 1986; Bolton and Dewatripont, 1994), or have started out from pure common interest games (Camerer and Knez, 1996); accordingly, such work downplay incentive issues. However, it is usually argued, and generally agreed, that while this approach can further the understanding of those aspects internal organization that relate to information processing, it cannot explain the existence and boundaries of organizations (Williamson 1985; Hart, 1995; Foss, 1996). To see how incentives may conflict in a non-organizational (market, small numbers bargaining) context, and how organizational governance can remedy particular kinds of incentive conflicts, but possibly also introduce new ones, consider a simple example.

\section{An Example}

The example (which is borrowed from Wernerfelt, 1994) lays out the basic logic of "incomplete contracting" theory, one of the dominant current in organizational economics. The specifics cannot automatically be transferred to other approaches, but the fundamental reasoning and assumptions are quite similar. The example is illustrated by the strategic-form games shown in Figure 1.

[Figure 1 about here]

Following Hurwicz (1972), one can imagine economic agents choosing game forms, and the resulting equilibria, for regulating their trade. Although the example only highlights two agents (players), "B" can initially be taken as representative of a number of potential agents (e.g., firms)

\footnotetext{
${ }^{4}$ Notions of agents as information processors and as facing attention allocation problems are sometimes loosely developed, but such insights are seldom cast within an overall optimizing logic. Moreover, motivational issues are seldom highlighted in this branch of organizational theory.
} 
that might want to cooperate with A. That is, "large numbers" conditions obtain, and we can think of the situation as taking place, at least initially, in a market setting.

Assume that agents initially want to regulate such trade under conditions where they maintain their independence (i.e., they are distinct legal persons). Efficiency requires that agents choose the game form and equilibrium that maximizes the gains from trade. The two players begin by confronting Game 1. In this game, the Pareto criterion is too weak to select a unique equilibrium, since both $\{$ up, left $\}$ and $\{$ down, right $\}$ may be equilibria on this criterion. However, the $\{$ down, right $\}$ equilibrium has a higher joint surplus than the $\{$ up, left $\}$ equilibrium, so that it will be in A's interest to bribe B to play \{right\}. Surplus maximization suggests that this equilibrium is the agents' preferred one. Their problem then is to design a contractual arrangement that will make choose strategies such this equilibrium results. Note that this problem captures the spirit of work on specific investments (Klein, Crawford and Alchian, 1978; Williamson, 1985; Hart, 1996) in which an agent (or possibly both agents) has to choose a strategy (in this case $\{$ right\}) that while surplus maximizing (when the other agent plays his best-response strategy) is not necessarily attractive for the agent (he only gets 1).

The apparent solution is choose a side-payment, $\mathrm{u}$, which can be chosen $(1<\mathrm{u}<2)$ to implement the equilibrium where A plays $\{$ down $\}$ and B plays \{right\}. If the contracting environment is such that this contract can be (costlessly) written and enforced, the agents will choose the efficient strategies. Apparently, there is no need for organizational governance as defined here, and the small numbers bargaining situation is viable.

However, different contracting environments may give different results. For example, it may be too costly to describe all contract stipulations in a comprehensive manner (e.g., "u" may be intangible, such as "goodwill", and hard to precisely describe). This may happen because of information costs, the limitations of natural language, the unavoidable emergence of genuine novelties, etc. The contract ends up being incomplete. Or, while the parties may be sufficiently smart to write down all the manifold possible aspects of their relationship, a third party who is supposed to enforce the contract does not have the wits to efficiently enforce the contract (Hart, 1990). In the latter case, contract terms are said to be "non-verifiable." Or, the costs of contracting may outweigh the gains (Saussier, 2000). In all of these cases, it may not be possible to sustain the first-best outcome, that is, the one that unambiguously maximizes joint surplus. In the context of the example, A may confronted with a contingency that is not covered by the contract, 
refuse to pay B the bribe, and B may have no recourse. However, B may well have the wits to anticipate this possibility. Thus, the contract stipulating the side payment may not be sustainable in equilibrium (i.e., the outcome where the agents get [4-u, $1+\mathrm{u}]$ may not be sub-game perfect). Value is destroyed relative to the optimal outcome, because B will not rationally choose \{right\}.

Whether an efficient or an inefficient outcome occurs will in many situations be critically sensitive to the timing of the game. However, in the specific example, timing doesn't really matter if the contracting environment is such that the promise to transfer $\mathrm{u}$ in return for B playing \{right\} is, for whatever reason, a non-enforceable one: Thus, if A gives B the bribe before the game begins, $\mathrm{B}$ will not play \{right\}, which means that A will decide not to give $\mathrm{B}$ any bribe. And if A promises B to pay the bribe after game, B will realize that this will not be in A's interest, and will still play \{left\}. This captures the idea that agents that anticipate opportunism on the part of their contractual partner will refrain from taking efficient actions or making efficient investments. The bottomline is that contracts cannot completely safeguard against the reduction of surplus or loss of welfare stemming from incentive conflicts (given risk preferences).

The analytical enterprise is therefore one of comparing alternative contracting arrangements, all of them imperfect. A specific contracting arrangement is represented by the authority relation. This obtains when one of the players becomes an employee, accepting the other player's orders to play a specific strategy (e.g., \{right\}) against a compensation. In other words, the underlying idea is that transferring a transaction or activity from a market to an organization context means that the agreement will be honoured. According to, for example, Williamson (1985), the reason lies in a change of incentives: When an agent changes his status from independent entrepreneur to employee, he becomes less of a residual claimant. His incentives to engage in behavior that results in suboptimal equilibria are correspondingly diminished. In terms of the example, B (or A) may have nothing to gain from playing $\{$ left $\}$ (rather than \{right $\}$ ) once he has assumed employee status, and will therefore obey A's (B's) orders. The law regulating labor transactions may reinforce such “docility" (Masten, 1988), to use Simon's (1991) expression. Or, nonopportunistic behaviors may be sustained by the repeated nature of the employer-employee relation and the attendant build-up of valuable reputation capital (Kreps, 1990, 1996).

\section{Problems of Organizational Governance}

Internalizing a transaction or an activity, that is, transferring it from market to organizational governance, does not in general, however, allow the relevant players to reach the first-best situa- 
tion. In fact, Hart (1995) essentially argues that hold-up of the kind discussed can still take place within the hierarchy, ${ }^{5}$ so that the problem of choosing efficient organizational (e.g., should A internalize B or vice versa or neither) becomes one of choosing the mode that minimizes losses from opportunistic hold-up.

Moreover, if, as is usually realistic, asymmetric information conditions can be assumed to exist, "A internalizing B" (or vice versa) may merely transform the problem of contractual hold-up into a problem of moral hazard, that is, B who has now assumed employee status faces lowerpowered incentives relative to the situation in which he was an independent agent/residual claimant, and may therefore shirk his duties. Recourse to high-powered incentives may be sought to alleviate such moral hazard, but this may be problematic to the extent that the employee is engaged in multi-tasking and some tasks are costly to measure: The provision of incentives for measurable activities may imply that other activities are neglected (Holmström and Milgrom, 1991), such as the proper maintenance of equipment (Williamson, 1985; Barzel, 1997; Hammond, 2000). In multi-tasking environments, high-powered incentives may therefore actually call forth morally hazardous behavior.

Note that such problems are not necessarily distinctly organizational. To be sure, the vast body of agency theory deals with incentive problems that may well beset internal organization; however, many of these problems, including multi-tasking problems, might also play out in a market context. However, organizations, or more narrowly, hierarchies, may be beset by distinct incentive problems. It is generally agreed that relatively little work has been done on organizational failures in this sense compared to the huge bodies of work on market failure (and political failure). However, some exists, mainly relating to what may be called the "costs of authority." A key theme in much of the work that is discussed in the present chapter (e.g., Coase, 1937; Williamson, 1996; Wernerfelt, 1997) is that the exercise of managerial authority in response to changes in the environment or in response to conflicts that are internal to the organization provide reasons why firms exist. Thus, the implicit thrust of most of this work is that managerial authority is always beneficial. ${ }^{6}$ There are, however, various incentive costs to the exercise of authority.

\footnotetext{
${ }^{5}$ Although the exact mechanisms through which this happens is somewhat opaque; perhaps one may imagine divisions holding each other up on transfer prices.

${ }^{6}$ It is arguable that one reason for this is that there is a tendency in the literature to think of the exercise of authority as being highly informed so that the right to control translates into effective actual control over decisions (see Foss,
} 
Rent-seeking. The best-known cost of authority is Milgrom and Roberts's (1988a) notion of "influence activities" and their associated costs (derived from the political economy literature on rent-seeking). Influence activities are agent's expenditures of time, effort, and tangible resources aimed at influencing decision makers to act in the agent's favor. The agent could be an individual seeking to curry favor with a supervisor, or a division manager seeking to acquire a greater share of corporate resources (Scharfstein and Stein, 2000). Such behavior is costly to the firm not only because of the opportunity cost of the agent's time, but also because the principal receives biased signals of the agent's performance and characteristics. To minimize costly rent-seeking firms can reduce the discretion of principals, relying on fixed rules (e.g., for promotions and favorable assignments) rather than the discretion of supervisors. This reduces the principal's ability to intervene where appropriate, however.

Selective intervention. Williamson (1985: 132) raises a fundamental issue: "Why can't a large firm do everything that a collection of small firms can do and more?" Consider two competing firms. Net gains may be expected from a merger, because of savings on overheads, economies of scale, coordination of pricing decisions, etc. Little needs to change on the level of organization. What were previously autonomous firms may now be units with semi-autonomous status. Importantly, incentives may be as high-powered as they were prior to integration. The decisions that are most efficiently made at the levels of operations will be made there. "Intervention at the top thus occurs selectively, which is to say only upon a showing of expected net gains" (Williamson 1985: 133). This implies that the combined firm can do everything the stand-alone firms could and more, so that"... integration realizes adaptive gains but experiences no losses" (p.161). Clearly, the argument implies that merger activity will go on until all economic activity is undertaken by one single firm. Since this flies in the face of the evidence, selective intervention must be associated with some "losses" that offset the benefits of integration at the margin.

Williamson (1985: 161) points to various commitments problems that are accompany. Thus, it may be costly for the firm that takes over another firm to make it credible that it will honor promises regarding, for example, transfer prices or promotion prospects, the costliness stemming from a lack of third-party enforcement. Milgrom and Roberts (1996: 168) argue that “... the very

2002). However, the right to decide need not confer effective control over decisions, as Aghion and Tirole (1997) point out. In their story real authority is determined by the structure of information in the organization. An increase in an agent's real authority is assumed to promote initiative, but also to lead to control losses from the point of view of the principal. 
existence of centralized authority is incompatible with a thorough going policy of efficient selective intervention. The authority to intervene inevitably implies the authority to intervene inefficiently" (see also Coase [1937] on managerial mistakes).

In an attempt to flesh out such inefficient intervention Baker, Gibbons, and Murphy (1999) (theoretically), Foss (2003) and Foss, Foss and Vazquez (2006) (empirically) focus on managerial problems of committing to not over-ruling employees. Note that managerial intervention will often not only consist of making those decisions that cannot be made on lower levels on the basis of existing routines, procedures, etc. (Selznick, 1957: Chpt. 1), but will typically also override existing instructions of employees (Tepper and Taylor, 2003). Moreover, in firms where employees are given considerable discretion, managerial intervention may amount to overruling decisions that employees have made on the basis of decision rights that have been delegated to them. This suggests that employee utility may be harmed by managerial intervention which damages motivation, so that net losses from such intervention are conceivable. From the point of view of organizational governance, the design problem is to maximize managerial intervention "for good cause (to support expected net gains) while minimizing managerial intervention "for bad [causes] (to support the subgoals of the intervenor)" (Williamson 1996: 150-151). Akin to Milgrom and Roberts's (1988a) argument that a hierarchical structure minimizes rent-seeking by subordinates, Foss, Foss and Vasquez (2007) argue that traditional hierarchies have advantages with respect to limiting the incentive costs of managerial intervention. Thus, while first-best selective intervention" is indeed strictly impossible, second-best intervention is feasible.

\section{Overall Characteristics of Rational-Choice Approaches to Organizational Governance}

The above normal form game representation has been chosen as an illustrative device not because game theory is a preferred analytical vehicle for doing organizational economics research, but because it helps to identify a number of the crucial underlying assumptions in organizational economics, assumptions that sharply differentiate organizational economics from other organization studies approaches.

Methodological individualism. In accordance with its legacy in mainstream economics and its rational-choice methodology, organizational economics is entirely methodological individualist, and may even be argued to pursue a "hard" methodological individualist program: The aim is to explain contractual and organizational forms fully in terms of individual action and interaction (without remainder). While, of course, organizational incentives and other means of organiza- 
tional governance influence the decision situations that organizational members find themselves in, these organization level phenomena are fully explained in terms of individual action and interaction. Moreover, "soft" organization-level constructs, such as "trust," "embeddedness," "organizational cognition," "capabilities," etc. are not part of the explanans of the modern theory of the firm, and are only rarely treated as explanandum phenomena (but see, e.g., Kreps [1990] on culture and Aghion and Tirole [1995] on core competence). These features arguably give organizational economics a "state of nature" or "under-socialized" character that has been subject to a great deal of critique (Granovetter, 1985; Freeman, 2002). They also set organizational economics apart from many other approaches in the overall the field of organization studies approaches, some of which are explicitly methodologically collectivist (Abell, Felin and Foss, 2007; Felin and Hesterly, 2007).

Rationality and efficiency. It should be evident from the preceding that the material covered in this chapter falls within the orbit of what organizational sociologists (e.g., Scott, 1992) call "rational" organization theory approaches. The notion of "rational" as used by organizational sociologists usually involves a both more expansive and looser meaning than the one ascribed to it in organizational economics in which it strictly refers to properties of individual agents. Economists seldom apply the notion of rationality to supra-individual entities. Instead, they enter efficiency land. Arguably, this reflects economists' strong commitment to methodological individualism, one of the uniting features of all rational-choice approaches to organizational governance. In terms of what is assumed about behavior, all organizational economists are located within the rational-choice camp. To be sure, bounded rationality (Simon, 1955) has been invoked by many organizational economists, notably Williamson, but it is characteristic that the use that is actually made of bounded rationality is quite limited. For example, the attempt is not to characterize real decision-making (á la the Carnegie-Mellon approach to organization theory, March and Simon, 1958; Cyert and March, 1963), but to use bounded rationality as an explanation of contractual incompleteness (Foss, 2003b).

Cognition. Particularly in its formal versions (e.g., Holmström, 1979; Grossman and Hart, 1986; Holmström and Milgrom, 1994) organizational economics follows standard economics in making strong assumptions about the cognitive powers of agents. This reflects a strong reliance on information economics and game theory. Some formal organizational economists have argued that there is no need for bounded rationality (even in the above weak sense): The contracting 
problems that are studied in organizational economics can be approached making use of the more tractable notion of asymmetric information (Hart, 1990). Relatedly, because of the Bayesian underpinning of game theoretical contract theory, "Knightian," "deep," "radical," etc. uncertainty has no role to play. (In the above representation, players can thus never be surprised). Even those organizational economists who have taken an interest in behavioral decision theory (e.g. MacLeod, 2002) have not in general strayed far from the paradigmatic expected utility model.

Much is taken to be given. In existing research, and reflecting the modeling approach of the literature, much is taken as given or "frozen" (Foss and Foss, 2000). The particular idealizations that are performed in the literature take several forms. For example, because of the strong assumptions that are made with respect to agents' cognitive powers, decision situations are always unambiguous and "given." The choice of efficient economic organization is portrayed as a standard maximization problem in the case of contract design or as a choice between given "discrete, structural alternatives" (Williamson 1996a) in the case of the choice of governance structures. There is no learning and no need for entrepreneurial discovery. In the above representation, strategies are thus given.

Motivation. Motivation is assumed to be wholly extrinsic (Frey, 1997); hence, stronger monetary incentives always call forth more effort (in a least one dimension). Moreover, motivation is entirely self-directed (i.e., there are no other-regarding preferences) (Fehr and Gächter, 2000). Finally, preferences are taken as given, and organizational governance has no role in shaping preferences. Organizational governance only shapes extrinsic motivation and possibly beliefs (because of signaling, see, e.g., Kreps, 1990; Benabou and Tirole, year).

The function of economic organization. Problems of economic organization may in generic terms be represented as games where the Nash equilibrium is not Pareto-optimal. While this formally includes, for example, coordination games of the stag-hunt variety (Camerer and Knez 1996), the main thrust of organizational economics is to sidested coordination type problems. The function of contracts, governance structures, and mechanisms such as reputation is to influence incentives in such a way that agents choose those strategies that result in the choice of an equilibrium that is Pareto-superior relative to the Nash equilibrium. By placing the whole explanatory emphasis on problems of aligning incentives, it is arguable that many coordination problems of organizational governance are placed outside of the explanatory orbit of organizational economics (Camerer and Knez, 1996; Langlois and Foss, 1999; Grandori, 2001). 
Mode of explanation. Efficient economic organization is supposed to be consciously chosen by well-informed, rational agents. Alternatively, evolutionary arguments are invoked, so that selection processes sort between organizational forms in favour of the efficient ones (Williamson 1985). Thus, explanation is either fully "intentional" or "functional-evolutionary" (Elster 1983; Dow 1987). For example, one may compare Nash equilibria that result from different distributions of bargaining power (for example, as given by ownership patterns) (Hart 1995). The link to observed economic organization is established by asserting that what is observed is also efficient, for example, because of the existence of effective selection forces rapidly performing a sorting among firms with different efficiencies. Alternatively, it is established by claiming because agents are supposed to be so clever that they can always calculate and choose optimal economic organization. $^{7}$

\section{A CLOSER LOOK AT RATIONAL-CHOICE APPROACHES TO ORGANIZATIONAL GOVERNANCE}

To speak of a "rational-choice" approach to organizational governance here is, in a sense, a reconstruction since it was only from the beginning of the 1980s that social scientists explicitly began to speak of a rational-choice approach at all. While economists began from rational-choice foundations much earlier, they have seldom or never not felt the need to stress the obvious. Thus, the relevant economics approaches are not usually talked about as "rational-choice approaches to organization" per se, but are applications of economics to organizational theory-called the "economics of organization," the "theory of the firm," or "organizational economics." While the preceding section identified some of the main methodological and substantive themes running through this current, the present section takes a more detailed view, organized chronologically and around key contributions.

\section{The Firm in Economics: Changing Conceptions}

Although economists have employed the notion of "the theory of the firm" at least since the early 1930s (e.g., Robinson, 1932), the meaning of the term has undergone subtle, but important changes, and it is only within the last decades that economists have generally recognized the

\footnotetext{
${ }^{7}$ In the words of Hart (1990: 699): "even though the agents are not capable of writing a contract that avoids hold-up problems, they are clever enough to understand (at least roughly) the consequences of their inability to do so". For a skeptical discussion of this feature, see Kreps (1996).
} 
need for distinct theorizing relating to the firm. Of course, economists have for a long time employed a distinct apparatus relating to the firm's cost curves, etc. Yet, firms were for a long time taken to be unitary actors on par with consumers, the internal organization of the firm being treated as essentially a black box. Indeed, the indifference curve/budget constraint analysis of basic consumer theory is virtually identical to the isoquant/isocost analysis that is used to derive the firm's cost functions (Boulding, 1942).

The "theory of the firm" as that term would have been understood by prominent inter-war economists, such as Pigou or Viner, is therefore something rather different from the meaning that more contemporary theorists, such as Coase, Williamson or Hart, would ascribe to it. This reflects the change of the theory of the firm from being concerned with developing a vital component of price theory, namely firm behavior, to being concerned with the firm as an interesting subject in its own right. At the same time the basic explananda of the theory of the firm has changed, from the firm's pricing decisions, combination of input factors, etc. to the questions of why firms exist, and what explains their boundaries and internal organization (Holmström and Tirole, 1989). (To capture the latter meaning, reference is in this chapter to "organizational economics").

That different questions are asked does not mean that organizational economics is developed in complete separation from more aggregate issues. For example, Coase (1992) sees it as an integral part of the "institutional structure of production"; Hart (2000) has applies his property rights approach to bankruptcy law; Williamson (1987) emphasizes the antitrust implications of transaction cost economics; agency approaches (Jensen and Meckling 1976) play an important role in the understanding of corporate governance systems; etc. However, it means that the modern view of the firm is a significantly less anonymous ideal type (in the sense of Schütz, 1964) than the firm in economics three or four decades ago, so that analytical attention is devoted to the manifold of organizational forms and the different combinations of governance mechanisms that characterize such forms. In addition, attention has been focused on governance structures that lie "between" the market and the firm governance structures.

\section{Coase and Beyond}

Frank Knight, in Risk, Uncertainty, and Profit (1921), was the first economist to explicitly argue that economic principles can render intelligible the different forms of business organization found in the real world. However, Knight was primarily interested in explaining the exis- 
tence of profit and the connection between his theory of profits and his theory of the firm is not entirely clear. Nevertheless, Knight hints at alternative explanations of the firm and internal organization, explanations involving morally hazardous behavior (Barzel 1987), non-contractibility of entrepreneurial judgment (Langlois and Csontos 1993; Foss 1993), and (this is the best known explanation) the optimal allocation of risk (Kihlström and Laffont 1979). The latter theory was in fact a critical point of departure for Coase in "The Nature of the Firm" (1937), the paper that is now conventionally regarded as the founding paper in the theory of the firm.

It is not surprising that this paper has achieved the status of a true classic: It succeeds in defining a clear program for research in organizational economics, define the key questions and provide answers to the question that all revolve around a new analytical category, namely that of transaction costs. Coase clearly argues for the explanatory centrality of incomplete contracts and transaction costs ("the costs of using the price mechanism"), and puts forward a basic contractual conceptualization of the firm and an efficiency approach to its explanation. Most importantly, he defines the main desiderata of a theory of the firm, namely to "discover why a firm emerges at all in a specialized exchange economy" (i.e. the existence of the firm), to "study the forces which determine the size of the firm" (i.e., the boundaries of the firm) and to inquire into, for example, "diminishing returns to management" (i.e., the internal organization of the firm. All this, Coase explains, can be reached by adding the category of "costs of using the price mechanism" to ordinary economics.

In following the program thus sketched, and certainly also in addressing the puzzles that Coase had left - notably the nature of the determinants of "the costs of using the price mechanism" - , most organizational economics is fundamentally Coasian. ${ }^{8}$ For various reasons, some of them explained above, Coase's seminal analysis was neglected for more than three decades in the sense that although its existence was known and acknowledged, it was not used (Coase 1972). ${ }^{9}$ For a long time, it did not give rise to a cumulative theory development. However, a few

\footnotetext{
${ }^{8}$ However, when reading Coase's paper today, one is struck by the absence of references to incentive conflicts, arguably the main explanatory focus of today's economics of organization. Rather, Coase's perspective emphasizes flexibility: in an uncertain world, there is a need for adaptation to more or less unanticipated events, and the employment relation, where " ... the factor, for a certain remuneration ... agrees to obey the directions of an entrepreneur within certain limits" (Coase 1937: 391; emph. in original), may meet that need. The obvious problem with this explanation is, of course, that a standard argument in favor of the market has to do with the market's superior adaptability/flexibility (Hayek 1945). Coase's analysis does not allow us to say when the firm can beat the market in terms of flexibility and vice versa.

${ }^{9}$ It is somewhat questionable how well it really was known. For example, Marschak (1965) in his overview contribution to The Handbook of Organizations on "Economic Theories of Organization" does not even mention Coase.
} 
relevant papers did appear in these Dark Ages for organizational economics, notably Simon (1951). Simon formalizes Coase's analysis, and explains the employment contract as an incomplete contract where the employer offers a wage in return for which the employee agrees to accept the directions of the employer. The contract is incomplete in the sense that the two parties are unable to write an enforceable contingent contract that fully specifies what the employee must do as a function of the state of the world. The employee will accept such an open-ended contract to the extent that he expects the directions that he will receive to lie within his "zone of acceptance."

\section{Analytical Advances as Driving Organizational Economics}

Apart from isolated contributions there was essentially no development of organizational economics until well into the nineteen-seventies. Of course, important work on organizations by economists was done, notably the managerial (Baumol, 1962; Williamson, 1963) and behavioral (Cyert and March, 1963) theories of the firm. While it is possible to see anticipations of organizational economics in these contributions (e.g., the managerial theory highlighted incentiveconflicts between firm owners and managers while the behavioral theory focused on incentive conflicts between intra-firm agents) none of these were taken up with addressing the fundamental desiderata of a theory of the firm as defined by Coase, that is, the explanation of the existence and scope of firms.

In Williamson's terms (1985), Coase's analysis awaited its “operationalization” for many decades. Coase (1937) had listed several sources of the "costs of using the price mechanism" that give rise to the institution of the firm. In part, these are the costs of negotiating and writing contracts. The "most obvious cost of 'organising' production through the price mechanism is that of discovering what the relevant prices are" (Coase 1937). A second type of cost is that of executing separate contracts for each of the many market transactions that would be necessary to coordinate some complex production activity. However, Coase had given little further details on transaction costs and their determinants. Coase's 1960 paper was more explicit on these issues, and although it was not a paper about economic organization per se, it is quite arguable that the 1960 paper put more analytical flesh on the explanatory skeleton of the 1937 paper. As Barzel and Kochin (1992: 25) argue:

In "The Problem of Social Cost" it is shown that when the cost of transacting is positive, rights are not perfectly well defined, and the Coase Theorem makes it 
clear that costly transacting must lower the attainable output. Thus, "The Problem of Social Cost," in pointing out a relationship between the output that can be attained from a given set of inputs and the form of organization governing these inputs, provides an elaboration useful in the study of the firm.

These links were probably first explicated in Alchian and Demsetz (1972), the first contribution to organizational economics that is explicitly based on the economics of property rights (and which, ironically, is strongly critical of Coase, 1937).

Microeconomists were at work either as applied price theorists, notably in the Chicago and UCLA traditions, or as mathematical economists who were preoccupied with refining the Walrasian model (incorporating public goods, refining the understanding of uncertainty, trying to find room for a medium of exchange, etc.) (Bowles, 2004). However, these two rather different occupations of the micro-economist gave important impetus to the construction of the expanding toolbox that assisted the takeoff of organizational economics in the mid-nineteen seventies. So did other theoretical developments throughout in the nineteen-fifties and nineteen-sixties. The contributions took place on somewhat different levels. Some were purely analytical in the sense of furthering, for example, the conceptualization of uncertainty in the Walrasian model (e.g., Radner, 1968), while others were of a more basic, almost methodological nature, such as the growing appreciation of the notion that there are imperfect institutional and contractual alternatives for governing transactions and activities (Coase, 1960, 1964; Demsetz, 1969), and that transaction costs play a key role in understanding the relevant imperfections. Among these, partly overlapping, developments are, first, three partly overlapping developments that are all associated with the name of Kenneth Arrow:

Social choice theory and related work. Arrow's (1951) doctoral dissertation is one of the first and most celebrated attempts by rational-choice scholars to seriously grapple with issues of non-market decision making. Among the many implications of Arrow's work is the, albeit highly abstract, rationale it provided for phenomena such as leadership and hierarchical governance (e.g., as means to eliminate Condorcet cycles) (see Hammond and Miller, 1985). Work by Anthony Downs $(1957,1967)$ also examined non-market, democratic decision making, looked into the economic nature of hierarchies, and became hugely influential with respect to advancing rational-choice approaches in political science. Public choice theory, founded by James Buchanan and Gordon Tullock (1962), looked into constitutional issues on the basis of a contractarian approach that became a paradigm mode of explanation in organizational economics (Bowles and 
Gintis, 1988). All these currents legitimized a concern with non-market decision making by demonstrating the explanatory power of rational-choice theory in this context.

Work on welfare economics and information economics. Arrow was also a pioneer in the introduction of asymmetric and imperfect knowledge - although key advances had been made earlier, notably by Hayek (1945) — for the understanding of the functioning and welfare properties of markets, such as insurance markets (e.g., 1969, 1971). Early work highlighted the problem of moral hazard (Arrow, 1962). By employing a counterfactual style of reasoning Akerlof's (1970) study of lemons markets became central to subsequent work in the following decades that explicated how institutions and contracts emerge to handle problems associated with asymmetric information. An overall implication of his work was that firms can be understood as responses to market failures that arise under conditions of externalities and information asymmetries.

Bringing the Walrasian model closer to reality. Very related developments in took place in design and planning oriented work that aimed at applying the Walrasian model (Debreu, 1959) to issues of large scale planning and problems of taxation that involved eliciting information from agents. By making states of nature unobservable to some agents (moral hazard) or to the auctioneer (adverse selection) (Guesnerie 1992), this research stream succeeded not only in relaxing the Walrasian model; it also furnished tools that could be transferred from an economy-wide context and be successful applied to the study of certain classes of small numbers interaction (e.g., between a principal and an agent)

A parallel, but less formal set of developments that may be associated with Coase, are the following two strongly overlapping (cf. Barzel and Kochin, 1992) ones:

Property rights economics and law and economics. A key insight of Coase (1960) was the argument that exchanges are exchanges over property rights rather than over goods and services. At roughly the same time Alchian (1958) developed the same insight. This idea gave rise to a spate of influential work in the 1960s under the heading of "property rights economics" (as briefly summarized earlier in this chapter), a stream of research that strongly stressed its applicability beyond the market institution (e.g., Alchian, 1965). The file of law and economics also emerged essentially from Coase's paper and from oral tradition at the University of Chicago Law School, which stressed the possible efficiency properties of "non-standard" contracting practices. These fields promoted a comparative institutionalist approach (Demsetz 1969), provided the first working definitions of transaction costs as the costs of defining, exchanging and protecting property 
rights, made a link to relevant fields of law (notably contract law), and championed a basic efficiency approach, according to which observed economic organization should, at least as a first approximation, be seen as least cost responses to exchange problems.

Chicago-UCLA work in industrial organization. This kind of work rejected technological and monopoly explanations of observed contracting practice, and adopted a comparative contracting, and proto-transaction cost, approach (e.g., Director and Levi 1956). Williamson (1985: 19) argues that as a result of this kind of work, economists began, in the ten years between the celebrated Schwinn (1967) and GTE-Sylvania (1977) cases, to incorporate transaction cost considerations into their understanding of vertical restrictions.

In sum, organizational economics may seen as part of and growing out of a broader (if hardly concerted) attempt to move beyond the confines of the market institution and also inquire into the rationales and functioning of alternative institutions for resource allocation (see also Arrow 1987; Furubotn and Richter 1997; Salanië 1997; Bowles, 2004), parts of which are often summarized under the heading of "the new institutional economics." 1011 The fact that the above developments to a large extent took off independently and continued for a long time to develop independently helps explaining the presence of different streams of research in the modern theory of the firm. For example, "nexus of contract theory" is largely an outgrowth of the nineteen-sixties' (almost exclusively verbal) work in property rights economics, whereas "formal agency work" is largely an outgrowth of often highly mathematical work that aimed at making the Arrow-Debreu

\footnotetext{
${ }^{10}$ A certain, limited interaction with neighbouring disciplines has also played a role for the development of the theory of the firm. Thus, Oliver Williamson's interaction at Carnegie-Mellon University with the likes of Herbert Simon, Richard Cyert and James March as well as his reading of Alfred Chandler's (1962) accounts of American business history did play a role for the development of the transaction cost economics approach (Williamson 1996b). Still, it is surely debatable how deep the impact on the theory of the firm of insights from fields such as psychology, sociology, business history and business administration have really been. The overwhelming tendency has been to show how economics may give alternative accounts of organizational phenomena, or, in the case of business history, take un-theorized insights as grist for the organizational economics mill. Some economists have made more explicit attempts to develop an interdisciplinary approach to organization. Williamson is the most obvious example. Thus, Williamson has actively sought to incorporate what he considers to be crucial insights of not only psychology and business history, but also law (e.g., Williamson 1979). However, Williamson's subtle use of the work of legal scholars such as Ian Macneil is hardly reflected in other parts of the theory of the firm, or, if they are, they are blackboxed under the heading of "costly verifiability."

${ }^{11}$ The increased division of labour in economics has also played a role for the emergence of the theory of the firm, not only in the sense that its emergence is in itself an instance of specialization, but also because of the parallel emergence of neighbouring fields, such as labour economics, corporate governance, corporate finance, and public choice theory with which the theory of the firm has had interaction and from which inspiration has been gained. Relatedly, since at least the beginning of the 1970s economists have become more interested in "micro" issues more generally, rather than the more holistic or aggregate concepts that had dominated some fields.
} 
model more realistic. However, the two bodies of theories are concerned with rather overlapping themes; what is different is perhaps most of all the style of theorizing.

On the basis of the above influences and developments, work began to blossom within the theory of the firm in the mid-nineteen-seventies. As already mentioned, as late as 1972 Coase lamented that his 1937 paper had been "much cited and little used". However, at the time of Coase's lamentation, serious work on the theory of firm had begun to take off, notably with Williamson (1971) and Alchian and Demsetz (1972). These two seminal contributions already marked the beginning of a branching in the Coasian theory of the firm, for in retrospect it is evident that they helped found distinct perspectives. ${ }^{12}$ Other approaches also took off in the beginning of the nineteen-seventies, primarily the team-theoretic approach of Marschak and Radner (1972) and the evolutionary theory of the firm (Nelson and Winterm 1974). What has more recently become known as "contract theory" also began approximately in the beginning of the nineteen-seventies with the first contributions to formal principal-agent theory (Ross 1973). The result was what Demsetz (1997) has called a "quiet revolution" in economics.

\section{Research Streams in Organizational Economics}

The emphasis so far has been on what unites those research streams that cultivate a rationalchoice approach to organizational governance. It is now time to look more closely at the differences between these streams. On closer inspection, rather marked differences appear, for example, with respect to something so fundamental as how transaction costs should be conceptualized and explained and what are their consequences. For example, one stream highlights contractual incompleteness, where this may be explained by pointing to the ink costs of drafting long complex contracts. Another stream highlights the costs of measuring productivity. A related distinction has to do with whether one begins from complete contracts, that is, contracts that have all relevant decisions depending on verifiable variables, or not (see Tirole, 1999).

One may broadly interpret this diversion in the literature as stemming from different departures from the Arrow-Debreu model. Since firms cannot exist in this model, it is necessary to break with one or more of the Arrow-Debreu assumptions, particularly those relating to contracting. Two important assumptions in the Arrow-Debreu model are 1) the assumption of complete

\footnotetext{
${ }^{12}$ For example, when Hart (1989) introduces a distinction between "transaction cost economics" and "the firm as a nexus of contracts view", he is referring to traditions that were largely founded by the Williamson and the Alchian and Demsetz papers, respectively.
} 
contracting (agents can foresee all future contingencies and costlessly write contracts covering all contingencies, so that there are no incomplete contracts), and, 2) the assumption of symmetry of information concerning "states of nature" (so that there are no principal-agent incentive problems of either the moral hazard or adverse selection variety).

Incomplete contracting theories break with assumption 1), that is, they are founded on the assumption that it is for some or another reason costly to draft complex contracts, and that there is therefore a need for ex post governance. In particular, Williamson has for a long time put much emphasis on contractual incompleteness, and Grossman and Hart (1986) made the incomplete contracting methodology fashionable among formal economists of organization.The earlier game theoretical example highlighted the basic mechanics of incomplete contracting theories. Complete contracting theories break with assumption 2). Thus, they allow agents to write elaborate contracts characterized by ex ante incentive alignment, but only under the constraints imposed by the presence of asymmetric information and (divergent) risk preferences. Thus, although the contracts are complete, they are still different from Walrasian contracts (which may be called "perfect").

The following sections discuss in greater detail the contents of various streams within organizational economics, namely the nexus of contracts stream, formal principal-agent work, incomplete contracts: the coordination view, and incomplete contracts: the asset specificy/property rights view. ${ }^{13}$ Table 1 below provides an overview of the specific streams of research that may serve as a point of reference for the following.

\section{[Insert Table 1 about here]}

\section{The Nexus-of-Contracts View}

The "nexus-of-contracts view" (Hart, 1989), aka the "measurement branch of transaction cost economics" (Williamson, 1985) derives its name from a passage in one of the best known contributions to this stream, namely Jensen and Meckling (1976: 311):

\footnotetext{
${ }^{13}$ Admittedly, this clustering is in some cases relatively imprecise. For example, there are rather deep-seated differences between the work of Oliver Hart and that of Oliver Williamson (who are both put in the incomplete contracts: the asset specificy/property rights branch), not the least with respect to how rationality should be modelled, and they are therefore only reluctantly grouped together. And some principal-agent work may be argued to be merely formalizations of earlier verbal insights. Nevertheless, there are reasons to believe that the present clustering is the best possible. For example, in the case of Hart and Williamson, they share one overriding concern that sets them apart from other streams of research: the centrality in their stories of specific assets.
} 
The private enterprise or firm is simply one form of legal fiction which serves as a nexus for contracting relationships and which is also characterized by divisible residual claims on the assets and cash flows of the organization which can generally be sold without permission of the other contracting individuals.

Similar reasoning can be found Alchian and Demsetz (1972), in Fama (1980), and, perhaps most forcefully, in Cheung (1983); indeed, Cheung goes as far as doubting whether it is at all productive to use the very notion of "the firm". Much more is at stake here than a methodological individualist scepticism of working with aggregate social entities. The theoretical point is that it is misleading to draw a hard line between firms and markets (a key point in Coase, 1937). Firms are legal entities, and this has important economic implications (e.g., limited liability, the right to deduct input purchases from tax statements, infinite lifetime, etc.), but they are nevertheless best seen as merely special kinds of market contracting. What may distinguish them relative to other market contracts lies primarily in the continuity of association among input owners (see also Demsetz, 1988). We may perhaps talk about a nexus of contracts being more "firm-like" when, for example, residual claimancy becomes more concentrated, but it is not in general productive to talk about "firms" as distinctive entities.

As Alchian and Demsetz (1972) explicitly argue, a consequence of this view is that the distinction between the authority-based and the price-based modes of allocation, so strongly emphasized by Coase (1937), is superficial. In reality, they argue in a famous passage, there is no basic difference between "firing" one's grocer and firing one's secretary, and what looks like a long, open-ended employment contract is in reality a cover for a continuous process of implicit negotiation between employers and employees. In an early formulation of the agency problem, Alchian and Demsetz argue that what is peculiar about the firm relative to other instances of market contracting is "team production" (i.e., production with inseparable individual production functions). This technology implies that marginal products are costly to measure, which creates a free rider problem, as team-production can be a cover for shirking. The solution to this problem is to appoint a monitor who is given the right to fire and hire members of the team, based on his observation of employees' marginal productivities. Giving him rights to the residual income of the team furthermore means that he is given incentives to perform the efficient amount of monitoring. This arrangement results in a specific form of organizational governance, namely the distribution of rights known as "the classical capitalist firm". Thus, the firm is explained in terms of the reduction of post-contractual measurement cost. 
As has been pointed out many times since the publication of Alchian and Demsetz (1972), their view raises problems: The monitor need not be the same person as the employer, but may an employee of a firm, specialized in monitoring services (Holmström and Tirole 1989). Is it really meaningless to speak of authority if the employer/monitor has the right to deprive the employee of the right to work with his tools and equipment to which the employee may be specialized (Hart, 1989). More firms seem to be observed than can be explained by team-production (e.g., conglomerates). While firms indeed consist of collections of contracts, intra-firm contracts may be qualitatively different from inter-firm contracts; for example, courts will rarely intervene in intra-firm disputes, leaving the firm's managers as the ultimate authorities for resolving disputes (Williamson, 1996a). Still, Alchian and Demsetz (1972) is a seminal contribution that is still heavily cited and continues to inspire work.

Jensen and Meckling (1976) which may have been even more influential than Alchian and Demsetz (1972), is in many ways an extension of the Alchian and Demsetz' reasoning to more fully include the agency problem between owners and managers. However, a crucial difference is that Jensen and Meckling do not think of team-production as essential to explaining the corporation. Instead, organizational governance is structured so as to minimize all sorts of agency costs, which they define as 1) the costs of monitoring, 2) bonding costs (i.e., credible commitments), and 3) the residual loss (evaluated relative to the actions that would maximize the principal's welfare). Using this definition, Jensen and Meckling focus on the agency costs of outside equity and debt, and define optimal capital structure as the combination of debt and equity that minimizes agency costs. ${ }^{14}$ Thus, much of the nexus of contracts stream has consisted of critical departures from Alchian and Demsetz. ${ }^{15}$ However, their paper also inspired formal work. An important example is Holmström (1982), itself something of a recent classic. In contrast to Alchian and Demsetz, who focuses on input monitoring as the solution to the team problem, Holmström's focus is on how to provide (monetary) incentives to solve the team problem.

\footnotetext{
${ }^{14}$ Important subsequent work in this stream include Fama (1980) and Fama and Jensen (1983) are both essentially critiques and extensions of the Jensen and Meckling paper, Fama highlighting the role of the managerial labor markets in disciplining firm management, Fama and Jensen further elaborating on the division of labour between decision management and decision control (see also refs.).

${ }^{15}$ Jensen and Meckling (1992) is testimony that the nexus of contracts research tradition has at least until recent been vital. They more explicitly bring in the notion of decision rights - which may have been comparatively neglected relative to the notion of residual claimancy in this stream of literature - and combines it with a perspective on local knowledge that is derived from Hayek (1945). Like markets, firms are repositories of local knowledge and a key organizational design problem is getting right the allocation of decision rights which translates into finding the optimal trade-off between losses from agency problems and benefits from a fuller use of local knowledge.
} 
Holmström famously demonstrates that in a team-production situation with unobservable effort levels, three rather basic requirements that one can sensibly ask of the incentive system cannot be met. These are Nash equilibrium, budget balancing (that is, the revenues should be fully distributed among the team-members by the incentive system) and Pareto optimality. Specifically, a budget-balancing incentive system cannot reconcile Nash equilibrium and Pareto optimality. The reason? The fact that every team-member equalizes marginal costs and benefits of additional effort, which implies that if one team member's effort generates some extra revenue for the team, he should be given that revenue in order to be properly motivated; however, under the requirement of budget balancing this obviously cannot be done for all team-members. In this perspective, the central advantage of the firm is that third parties (other units, shareholders) can be made sinks so that the team does not not have to balance its budget.

Historically, both nexus of contracts theory and principal-agent theories (or simply, agency theory) are often argued to reach back to early debates on the shareholders/managers relation. Following the observation by Berle and Means (1932) that ownership of US firms allegedly had become separated from management and control, managerialist theories modeled firm behavior as the maximization of managerial objectives (firm size, growth, sales maximization) under a profit constraint (Williamson 1964). The story that was told to explain this was that managerial objectives were positively correlated with managerial compensation and power. The attendant conflict of interest is, of course, an example of a principal-agent conflict. Indeed, work on this conflict forms the theoretical backbone of most of the heavily expanding field of corporate governance.

\section{Formal Agency Theory}

Formal work on agency theory takes off at about the same time as the nexus of contracts approach, but only fully picks up steam in the nineteen-eighties with all sorts of extensions of the basic model, such as layers of principal-agent relations, multiple agents, agents that carry out multiple tasks, agents that can collude, long term PA setting and much else. ${ }^{16}$ Indeed, in the 1980s, principal-agent models became virtually synonymous with "contract theory."17 The ca-

\footnotetext{
${ }^{16}$ See Hart and Holmström (1987) for an early survey and Laffont and Martimort (2002) for a more recent and very comprehensive treatment.

${ }^{17}$ At least until Grossman and Hart [1986] defined a new stream within contract theory, namely the "new" property rights perspective.
} 
nonical agency models are formal representations of the situation in which an informed party trades with an uninformed party, and where the private information in question may either concern what the agent does ("hidden actions") or who he is ("hidden characteristics"). Models are conventionally classified according to the timing of the moves in the corresponding games (i.e., if the informed or the uninformed party moves first) (Salanié, 1997; Laffont and Martimort, 2002): There is a distinction between adverse selection models (where the uninformed party is imperfectly informed of the characteristics of the informed party); signalling models, which have the same informational structure but in which the informed moves first; and moral hazard models, in which the uninformed party moves first but is imperfectly informed of the actions of the informed party (ibid.: 4).

The agency problem in its moral hazard manifestation basically stems from a conflict between insurance and incentives. The theory of optimal insurance demonstrates that sharing profit between a risk-neutral principal and a risk-averse agent (i.e, standard assumptions about risk preferences in the agency literature) has the risk-neutral principal bearing all of the risk. This leads to the first-best outcome. However, this is only if incentive issues are set aside (or the agent has no choice of action). In the standard bilateral setting, the principal in fact cannot propose a first-best contract to the agent because the agent's action is assumed not to be verifiable; hence, cannot be written into the contract. The asymmetric information in question may be a matter of either hidden action or hidden knowledge (i.e., the principal does not know some characteristics of the agent that are relevant to the relation). The (moral hazard) problem then is that the agent selects an action which has random consequences, and those consequences are verifiable, but the action and the state of nature (that both "produced" the consequences) are not. In this case, risksharing and incentive considerations will interact. The contract will specify a reward schedule so that the agent is paid by the principal as a function of the verifiable consequences. In general, such a contract will only be second-best. This basic analysis is set out already in Ross (1973).

Holmström (1979) is arguably the next truly major contribution to formal agency theory. The starting point for the analysis is the idea that when only pay-offs/outcomes can be observed, optimal contracts will be second-best because of the problem of moral hazard. However, creating additional information systems (such as accounting) or in other ways extracting extra information about the agent's actions or states of nature, it is possible to improve on contracts, even though the additional information may be imperfect. Holmström derives a necessary and suffi- 
cient condition for additional information to be valuable. This is a clearly an important step towards an economic approach to such important phenomena as accounting systems or management information systems, and Holmström's work has been of substantial inspiration for scholars who adopt formal, rational-choice approaches to understanding such aspects of organizational governance (e.g., Antle and Demski, 1988).

In general, principal-agent theory has brought a wealth of insights that are helpful for understanding contractual arrangements in general and important dimensions of organizational governance in particular. Agency models highlight the tradeoff between providing high-powered incentives (to encourage agent effort) and insuring risk-averse agents against events beyond their control (making it easier to attract and retain agents). Most of the applied literature in corporate finance and corporate governance (executive compensation, the structure of debt agreements, board composition, and so on) is based on agency theory. Holmström's (1979) “informativeness principle" suggests that principals should use all performance indicators that are available at low cost, to provide a more precise estimate of the agent's (unobservable) effort; this explains why executive compensation agreements tie compensation to multiple measures of performance such as accounting returns, stock performance, sales growth, market share, and the like. Holmström and Milgrom $(1991,1994)$ explore multi-task principal-agent models that show, as noted above, that pay-for-performance schemes based on objective performance metrics can induce a distortion of effort if some tasks are more easily observable than others. Under these circumstances, subjective performance measures may be valuable when used in conjunction with objective metrics (Baker, Gibbons and Murphy, 1994).

Contrary to common perception (e.g., Ghoshal and Moran, 1996), agency theory does not recommend that incentives in organization be made as powerful as possible. In a striking piece of work, Holmström and Milgrom (1991) wonder why payment schedules are usually simpler and less high-powered (even when good output measures are seemingly available) than basic agency theory would predict. The answer involves the idea that employees often work on multidimensional tasks. In this situation, incentive pay not only influences efforts and allocates risk; it also allocates the effort of agents across tasks. Some possibly essential tasks (or dimensions of a task) may be very costly to measure for the principal; as a result, the principal risks that the agent will allocate all his effort to tasks (dimensions of a task) that are easier to measure. If principals want agents to allocate effort to all tasks (dimensions of a task), they may be better off offering a 
fixed wage, that is, low-powered incentives (see also Gibbons [2005] for more detail). This also provides insights into job-design and task assignment, that is, issues of organizational specialization and roles: Tasks that are easily measurable may be bundled and assigned to certain kinds of jobs whereas costly-to-measure tasks are assigned to other jobs. Hard-powered incentives can be provided for the first kind of jobs but not the last kind.

Although agency theory in important ways further the understanding of organizational, agency theory is not a theory of the firm per se (Hart, 1989). The reward schedules that may modify the effects of asymmetric information are independent of any particular organizational structure. In principle, a reward schedule for a legally independent supplier firm may be completely identical to an employee reward schedule. Thus, principal-agent essentially does not discriminate between inter-firm and intra-firm transactions, whereas the main point of Coase is exactly that there is a fundamental difference.

\section{Incomplete Contracts: The Coordination Perspective}

Differences go farther, for it is notable that Coase (1937) did not emphasize, or even mention, incentive conflicts as a part of the understanding of organizational governance. ${ }^{18}$ Coase's (1937) explanation of organizational governance is probably best understood as a coordination theory: The firm is an institution that lowers the costs of coordination in a world of uncertainty (see further Langlois and Foss 1999). Of course, this view is closely tied to the view of the employment contract as the defining characteristic of the firm. As Simon (1951) points out an employee is distinguished from an independent contractor by the nature of his contract: While the employee is subject to the authority of the manager of the firm, an independent contractor acts autonomously. Simon (1951) compares the employment contract and the market contract thus understood in terms of efficiency. Whereas the market contract specifies the action to be performed in the future and its price, the employment contract specifies a range of acceptable orders and establishes the right of the employer and the duty of the employee to accept orders within this range ("the zone of acceptance"). As in Coase, the advantage of the employment relationship lies in its flexibility (see also Wernerfelt, 1997). The action of the employee can be adapted to whatever state of nature will occur. Simon also points out that the employment relationship is to some extent reliant upon the employer's reputation for not abusing his authority, a theme later

\footnotetext{
${ }^{18}$ In his assessment of modern organizational economics, Coase is explicitly critical of the overriding contemporary emphasis on incentive conflicts (Coase, 1991a).
} 
pursued by Kreps $(1990,1996)$. The need for trusting the employer is less if the employee is nearly indifferent between different tasks.

\section{Incomplete Contracts: Williamson's TCE and (New) Property Rights Perspectives}

Incomplete contracts theory of the two kinds under scrutiny here- the approach associated with Oliver Williamson and the one associated with Oliver Hart - are united in their focus on the organizational implications of ex post opportunistic behavior in the presence of relation-specific investment. There are, however, a number of differences that warrants a separate treatment (see also Bajari and Tadelis, 2001; Whinston, 2001; Williamson, 2000; Lafontaine and Slade, 2007).

Williamson. In a string of influential contributions, Williamson (e.g., 1971, 1975, 1985, 1996a) has built a theory that while built on Coasian foundations also incorporate ideas from psychology and contract law. The behavioral starting points in Williamson's theorizing are, first, Simon's concept of bounded rationality, which to Williamson implies the presence of contractual incompleteness and a need for adaptive, sequential decision-making. The second crucial behavorial assumption is that opportunism, which is defined as "self-interest seeking with guile". The implication of opportunism is that contracts will often need various types of safeguards, such as

"hostages" (e.g., the posting of a bond with the other party). The unit of analysis in Williamson's work is the multi-dimensional transaction. In addition to uncertainty (which is "frozen"), the dimensions of transactions that are primarily determinative of the costs of those transactions are frequency and asset specificity. In an early contribution, Klein, Crawford and Alchian (1978) linked asset specificity to the concept of appropriable quasi-rent:

Assume an asset is owned by one individual and rented to another individual. The quasi-rent value of the asset is the excess of its value over its salvage value, that is, its value in its next best use to another renter. The potentially appropriable specialized portion of the quasi rent is that portion, if any, in excess of its value to the second highest-valuing user (Klein, Crawford and Alchian 1978).

Following Klein, Crawford and Alchian, asset specificity has increasingly become the central character in Williamson's analysis. Williamson (1996) now identifies six different reasons why assets may be costly to redeploy, namely because of specialized knowledge (i.e., human capital specificity), attachment to a brand name, a need to take quick actions ("temporal specificity"), market size ("dedicated assets"), localization and physical characteristics. 
Specific assets open the door to opportunism. If contracts are incomplete due to bounded rationality, they must be renegotiated as uncertainty unfolds, and if a party to the contract (say, a supplier firm) has incurred sunk costs in developing specific assets (including human capital), that other party can opportunistically appropriate an undue part of the investment's pay-off ("quasi-rents") by threatening to withdraw from the relationship. This situation leads to a Paretoinferior outcome, for example, a no-trade outcome. Efficiency dictates the internalization within a firm of fransactions that involve highly specific assets. More generally, Williamson (1985: 68) argues that variety in contracts and governance structures “... is mainly explained by underlying differences in the attributes of transactions." The general design principle of discriminating alignment dictates aligning transactions that differ in the dimensions of uncertainty, frequency and asset specificity with governance structures which differ in the capacities to handle different transactions (cf. the earlier discussion of governance structures and governance mechanisms) in transaction cost discriminating way. Thus, specific constellations of (values for) uncertainty, frequency and asset specificity maps directly into specific governance structures. This is the main predictive content of Williamsonian transaction cost economics.

In Williamson's work (and in contrast to the new property rights view), contractual problems are often portrayed as essentially informational: It is defective information that is at the root of the inability of independent agents to establish efficient contracting. A Pareto-improvement may then be brought about vertical integration (Williamson, 1971, 1975). In Williamson's view, the hierarchy possesses certain inherent advantages over market contracting: “... when conflicts develop, the firm possesses a comparatively efficient resolution machinery. To illustrate, fiat is frequently a more efficient way to settle minor conflicts (say differences of interpretation) than is haggling or litigation (Williamson, 1971: 114).” Although it has been present in Williamson's work from the beginning, this advantage in particular has come to play an increasing role in Williamson's work. Thus, he has placed increasing emphasis on the argument organizational governance is characterized by its own implicit contract law, what he calls "forbearance". To illustrate, whereas divisions will not normally be granted standing for a court, corporate headquarters and headquarters function as the firm's "ultimate court of appeal". For example, Williamson (1991) points out that disputes which arise within the firm, for example, between different divisions, may be easier to resolve than disputes arising between firms which sometimes require the use of the court-system. Thus, managerial authority partakes of an important role as arbitrator in the face of conflicts and disputes over unforeseen contingencies; in other words, Williamson's ex- 
tension of the Coasian view of authority is to analyze it as a "private ordering," a private legal institution (Williamson, 2002). Part of that argument is Williamson's assertion that there are qualitative and quantitative differences between the information structures that are available under market contracting and those that are available in the firm, an argument put to work in Williamson's work on the M-form as an internal capital market (Williamson, 1975). These are claims that have disputed by what is often referred to as the new property rights theorists of the firm. ${ }^{19}$ In the words of Grossman and Hart (1986: 691): "the transaction cost-based argument for integration does not explain how the scope for such behavior changes when one of the self-interested owners become an equally self-interested employee of the other owner."

Hart: The New Property Rights Approach. This approach is often seen as a formal version and development of important elements in Williamson's work (but for a critique of this interpretation, see Kreps, 1996; Williamson, 2000; Lafontaine and Slade, 2007). In fact, the founding new property rights paper, namely Grossman and Hart (1986), was explicitly motivated by an attempt to model Klein, Crawford and Alchian (1978) and Williamson's ideas on asset specificity, using modeling conventions and ideas developed in (complete contracting) agency theory (particularly Holmström, 1982). However, the outcome of that attempt was essentially a new theory. This is because Klein, Crawford and Alchian as well as Williamson have unforeseen contingencies at the heart of their stories: It is the haggling that arises when contracts are pushed outside of their self-enforcing range by unforeseen contingencies that is the main problem here. What matters is the ex post action. In contrast, most of the incomplete contracting approach assumes that ex post bargaining is efficient and that actions (e.g., with respect to investment) are taken immediately after the contract is signed. Thus, what drives these models are misaligned ex ante incentives, particularly with respect to investment in vertical buyer-supplier relationships.

As in Williamson's work, a central assumption is that real-world contracts must necessarily be incomplete in the sense that the allocation of control rights cannot specified for all future states of the world (Grossman and Hart, 1986; Hart and Moore, 1990). Ownership is defined as the possession of residual rights of control, that is, rights to control the uses of assets under contingencies that are not specified in the contract. Thus, control implies the ability to exclude other agents from deciding on the use of certain assets, for example, the owner has the right to pull out the assets he owns from a relation. Such ownership rights can confer bargaining power, and play

\footnotetext{
19 "New" to distinguish these theorists from "older" property rights theorists such as Coase, Alchian, Demsetz, etc.
} 
an important role in the determination of the efficient boundaries of the firm. Thus, control rights that according to Hart and his associates determine the boundaries of the firm: A firm is defined as a collection of jointly owned assets.

The basic distinction between an independent contractor and an employee, that is to say, between an inter-firm and an intra-firm transaction, turns on who owns the physical assets which the agent utilizes in his work. An independent contractor owns his tools etc., while an employee does not. The importance of asset ownership derives from the fact that the willingness of an agent to undertake a non-contractible investment (say, exertion of effort or investment in human capital) which is specific to the asset depends on who owns the asset. If the agent who undertakes the investment does not own the asset, she may, as in Williamson's work, be subject to a hold-up by the owner. On the other hand, the ability to deprive an agent of the piece of capital with which she works (and to which she may be heavily specialized) is what provides a room for authority. Efficiency then dictates that the agent who is to make the most important (noncontractible) asset-specific investment should own the asset. It is not that opportunism can be avoided by internal organization/integration per se. Integration may shift incentives for opportunistic behavior, but it does not remove such incentives. Given this, one should choose the ownership arrangement that via its impact on incentives minimizes the consequences of opportunism.

Transaction cost economics and the new property rights view. Grossman and Hart (1986) and Hart and Moore (1990) were recognized immediately as path-breaking contributions to the study of incomplete contracting. Indeed, Williamson (1996a: 372-73) argued that TCE had progressed from "pre-formal” (i.e., Coase's work) to "semi-formal” (i.e., Williamson's own work) and "fully formal" (i.e., the new property rights view) stages. However, in a later discussion Williamson (2000) finds the new property rights finds it substantially different from his own framework in several key respects. For instance, formal incomplete-contracting models assume that levels of relationship-specific investments are completely unobservable and non-contractible; yet ex post bargaining over the division of the surplus is costless. ${ }^{20}$ Moreover, the Grossman-HartMoore approach emphasizes the direction of integration; even under integration, the firm's central managers cannot observe or verify subordinates' ex ante relationship-specific investments, so it matters whether integration results from Party A acquiring Party B or vice versa. In contrast,

\footnotetext{
${ }^{20}$ In his words: "GHM vaporize ex post maladaptation by their assumptions of common knowledge and costless ex post bargaining" (Williamson 2000: 605).
} 
Williamson argues that integration should be modeled as a hierarchy in which the allocation of decision rights is independent of the process by which integration occurred. Finally, bounded rationality has been issue of contention. Thus, whereas Hart (1990) explicitly denied the need in organizational economics for a notion of bounded rationality (but see Hart and Moore [2007] for a different view), to Williamson contractual incompleteness is clearly derived from bounded rationality (rather than from some assumed non-contractability of the use of the assets in a relation as in the property rights approach). To Williamson organization structure and information channels influence the boundedness of rationality (Williamson, 1970) and may for this reason have implications for value creation

Bajari and Tadelis (2001) show that ex post adjustments under incomplete contracting can be modeled formally as well. In their model, completeness and complexity are chosen simultaneously (and inversely); ownership gives the contracting party the right to modify the project design ex post. Under integration, the buyer can specify changes that maximize her benefit ex post, but at the cost of weaker incentive for the seller. The result is a model in which internal procurement is an increasing function of complexity

The incomplete contracting debate. Whereas debate between proponents of transaction cost economics and the new property-rights perspective has concerned which elements of the theoretical structure that should primarily be stressed (asset or investment specificity, costless or costly ex post bargaining, etc.), the property-rights approach has been more fundamentally contested concerning its fundamental logic. The point of contention is what may explain ex ante misaligned investment incentives. Under complete contracting, agents can 1) perfectly foresee contingencies, 2) write contracts, and 3) enforce these. The implication is that in order to dilute investment incentives, some transaction costs involving assumptions 1) - 3) must be invoked. Thus, some aspects of future trades cannot be foreseen and must be left to future negotiation, and/or writing costs mean that writing a complete contract is seldom optimal, and/or the parties' valuations are not verifiable by a court and therefore cannot be contracted over.

However, what is questioned by Maskin and Tirole (1999) and Tirole (1999) is whether such transaction costs constrain the set of feasible contracts relative to the complete contracting benchmark. If this is not the case, transaction costs are not sufficient to establish neither the possibility of inefficient investment patterns, nor a role for ownership (within the particular set-ups adopted in contract theory). According to these critics, the problems stems from the fact that al- 
though valuations are not verifiable, they may be still be observable by the parties, which implies that trade may be conditioned on message games between the parties. These games are designed ex ante in such a way that they can effectively describe ex post all the trades that were not described ex ante. The key to this argument is the assumption (which is routinely made in the new property-rights literature) that parties allocate property rights and choose investments so that their expected utilities are maximized, knowing (at least probabilistically) how payoffs relate to allocations of property rights and levels of investment. ${ }^{21}$ Maskin and Tirole (1999) then provide sufficient conditions under which the indescribability of contingencies does not restrict the payoffs that can be achieved, a sort of "irrelevance of transaction costs" theorem. As Hart and Moore (1999) point out, however, unless the contracts governing these message games are renegotiation-proof - that is, the parties can commit ex ante not to renegotiate ex post if the possibility of mutual gain arises - such contracts are not much better than the incomplete contracts in the original Grossman-Hart-Moore model (see also Segal, 1999). Moreover, the contracts governing these message games can be extremely complex and prohibitively costly (Anderlini and Felli, 2004).

\section{Extensions}

The critical point, associated with Williamson, that there is little ex post action in formal organizational economics implies that most of organizational governance is reduced to issues of ex ante incentive alignment and allocation of residual ownership rights. "Softer" but very real management and organizational governance issues such as how to cultivate organizational citizenship behavior, avoid breach of psychological contracts and the like, seem difficult to press into such an ex ante design-oriented perspective. However, organizational economists have made significant strides forward with respect to linking ideas on ownership and incentives to such softer issues.

A starting point is the fact that human capital is inalienable. However, as Rajan and Zingales (1998: 388) argue, 'there is a sense in which employees 'belong' to an organization ... This sense of belonging arises from the expectation 'good citizens' of an organization have that they will receive a share of future organizational rents". Starting from the new property rights perspective, they treat this kind of belonging in terms of "access", which means that agents are allowed to

${ }^{21}$ In the jargon of the literature, they can perform "dynamic programming," which essentially is intertemporal optimization with discounting in a stochastic setting. 
work with critical resources, specialize themselves relative to these resources and make themselves valuable in this way. Since a specialized employee can control her own specialized human capital, she now has additional power, although she doesn't possess more residual rights of control. In their theory, access may sometimes provide better incentives than ownership. Thus, Rajan and Zingales elegantly manage to incorporate "soft" aspects of organizations, such as power and the development of capabilities, into the incomplete contracts approach. In general, there are ample opportunities to make room for softer aspects of organizational governance in the context of the incomplete contracts approach. When it is difficult to write complete state-contingent contracts, for example, when certain variables are either ex ante unspecifiable or ex post unverifiable, people often rely on "unwritten codes of conduct", that is, on implicit contracts. These may be self-enforcing, in the sense that each party lives up to the other party's (reasonable) expectations from a fear of retaliation and breakdown of cooperation.

Such a line of inquiry is pursued in Kreps (1990). Roughly, Kreps argues that employers and employees may be seen as playing a prisoners dilemma-game, that with repeated plays a cooperative norm - which is interpreted as corporate culture - may be established, and that this established norm tells employees (as well as outside contractors) that firm management will not opportunistically take advantage of them. The firm is seen in Kreps' paper, not as a collection of physical assets but rather as a carrier of reputation capital. ${ }^{22}$

Baker, Gibbons, and Murphy (2002) further explore the "relational" aspects of incomplete contracting. As they point out, vertical relations should be characterized not only according to ownership (make or buy), but also according to frequency (one-time or recurring). For repeated transactions, the choice is not between "spot outsourcing" and "spot employment," but between "relational outsourcing" and "relational employment." Klein and Leffler (1981) noted that reputation can substitute for hierarchy in mitigating opportunistic behavior among trading partners. Baker, Gibbons, and Murphy (2002) add that asset ownership (in the Grossman-Hart-Moore

\footnotetext{
${ }^{22}$ A different way of incorporating softer aspects of organizations that also stays close to the spirit of the incomplete contracts/new property rights approach is provided by Klein (1988). However, he argues that rather than focusing on individual human or physical assets in the analysis of the boundaries of the firm, attention should be directed to what "organization ownership". An organization can obtain ownership of another organization's organization capital, that is, the firm-specific knowledge embodied in the organization's team of employees (what is sometimes called "capabilities"). This can alleviate the hold-up problem, for the reason that it is (after integration) hard for the now integrated team to hold up the acquiring organization. The costs of collective action may be prohibitive and the holdup attempt may be illegal.
} 
sense) affects parties incentives to renege on a relational contract, both outside and inside the firm.

They construct a repeated game in which a downstream party makes a non-contractible promise to pay a bonus to an upstream party for delivering high quality. Integration increases the downstream party's incentive to renege on the promise (under non-integration, if the downstream party reneges, the upstream party can sell the good to an alternative user). Non-integration, however, increases the upstream party an incentive to increase the value of the traded good to the alternative user, giving her a stronger bargaining position should the downstream party renege. The tension between these incentives gives rise to the trade-off between integration and nonintegration. The analysis is very much in the spirit of the incomplete-contracting approach, but extended to a repeated-game setting.

\section{Syntheses}

The above treatment of streams in organizational economics should not be taken to imply that they are equally important in today's organizational economics. In fact, the Coasian (in the original sense) emphasis on coordination on activities and knowledge rather than incentive conflicts is a theme that is pursued by only a few theorists (although very important work has emerged from this stream, e.g., Wernerfelt, 1997; Garicano, 2000). Very little work is being done within the nexus of contracts stream. The most viable streams on the contemporary organizational economics scene are agency theory, the new property rights approach, and empirical transaction cost economics. Moreover, similarities rather than differences are increasingly stressed and explicit syntheses are increasingly being forwarded.

The perhaps first ambitious attempt to define a synthesis, specifically of agency theory, property rights theory and the strong emphasis on authority characteristic of transaction cost economics, is Holmström and Milgrom (1994). Striking a Williamsonian chord, they emphasize the importance of viewing the firm as "a system", specifically as a coherent set of complementary contractual arrangements which mitigate incentive conflicts. It is misleading, they argue, to focus on any one single aspect of this coherent whole: The firm is characterized by the employee not owning the assets (a new property rights point), by the employee being subject to a low-powered incentive scheme (a multitask agency point), and by the employee being subject to the authority of the employer (a transaction cost economics point), and all are essential aspects of the same phenomenon. Speficially, these "incentive instruments" are complementary: For example, in the 
presence of measurement costs, it is important that a person who does not own the assets which he uses is not subject to high-powered incentives, since he then is likely to care too little for the assets. Likewise, low-powered incentives make it important for the employer to be able to exercise authority over the use of the employee's time, since otherwise the employee will lack the proper incentive to be productive. Due to this complementarity, it is logical that independent contracting has the exact opposite constellation of instruments from the employment relationship.

Foss, Foss, Klein, and Klein (2007) attempt to synthesize key concepts of organizational governance with the economic theory of entrepreneurship. They begin with Knight's (1921) concept of entrepreneurship as judgment. In Knight's formulation, entrepreneurship represents judgment that cannot be assessed in terms of its marginal product and which cannot, accordingly, be paid a wage (Knight 1921: 311). In other words, there is no market for the judgment that entrepreneurs rely on, and therefore exercising judgment requires the person with judgment to start a firm. Of course, judgmental decision makers can hire consultants, forecasters, technical experts, and so on. However, in doing so they are exercising their own entrepreneurial judgment. ${ }^{23}$ Judgment thus implies asset ownership, for judgmental decision-making is ultimately decisionmaking about the employment of resources. The entrepreneur's role, then, is to arrange or organize the capital goods he owns. As Lachmann (1956, p. 16) puts it: "We are living in a world of unexpected change; hence capital combinations ... will be ever changing, will be dissolved and reformed. In this activity, we find the real function of the entrepreneur."

One way to operationalize the notion of resource heterogeneity is to incorporate Barzel's (1997) idea that capital goods are distinguished by their attributes. Attributes are characteristics, functions, or possible uses of assets, as perceived by an entrepreneur. Assets are heterogeneous to the extent that they have different, and different levels of, valued attributes. Attributes may also vary over time, even for a particular asset. Given Knightian uncertainty, entrepreneurs are unlikely to know all relevant attributes of all assets when production decisions are made. Nor can the future attributes of an asset, as it is used in production, be forecast with certainty. Attributes are manifested in production decisions and realized only ex post, after profits and losses mate-

\footnotetext{
${ }^{23}$ In Foss, Foss, and Klein's (2007) terminology, the entrepreneur-owner exercises “original” judgment, while hired employees, to whom the owner delegates particular decision rights, exercise "derived" judgment as agents of the owner.
} 
rialize. ${ }^{24}$ Entrepreneurs who seek to create or discover new attributes of capital assets will want ownership titles to the relevant assets, both for speculative reasons and for reasons of economizing on transaction costs. These arguments provide room for entrepreneurship that goes beyond deploying a superior combination of capital assets with "given" attributes, acquiring the relevant assets, and deploying these to producing for a market: Entrepreneurship may also be a matter of experimenting with capital assets in an attempt to discover new valued attributes.

Such experimental activity may take place in the context of trying out new combinations through the acquisition of or merger with another firms, or in the form of trying out new combinations of assets already under the control of the entrepreneur. The entrepreneur's success in experimenting with assets in this manner depends not only on his ability to anticipate future prices and market conditions, but also on internal and external transaction costs, the entrepreneur's control over the relevant assets, how much of the expected return from experimental activity he can hope to appropriate, and so on. Moreover, these latter factors are key determinants of economic organization in modern theories of the firm, which suggests that there may be fruitful complementarities between the theory of economic organization and Austrian theories of capital heterogeneity and entrepreneurship.

Foss, Foss, Klein, and Klein (2007) show how this approach provides new insights into the emergence, boundaries, and internal organization of the firm. Firms exist not only to economize on transaction costs, but also as a means for the exercise of entrepreneurial judgment, and as a low-cost mechanism for entrepreneurs to experiment with various combinations of heterogeneous capital goods. Changes in firm boundaries can likewise be understood as the result of processes of entrepreneurial experimentation. And internal organization can be interpreted as the means by which the entrepreneur delegates particular decision rights to subordinates who exercise a form of "derived" judgment on his behalf (Foss, Foss, and Klein, 2007).

\footnotetext{
${ }^{24}$ As Alchian and Demsetz (1972, p. 793) note, "[e]fficient production with heterogeneous resources is a result not of having better resources but in knowing more accurately the relative productive performances of those resources."

Contra the production function view in basic neoclassical economics, such knowledge is not given, but has to be created or discovered. Even in the literature on opportunity creation and exploitation, in which entrepreneurial objectives are seen as emerging endogenously from project champions' creative imaginations, entrepreneurial means (resources) are typically taken as given (see, for example, Sarasvathy, 2001).
} 


\section{APPLICATIONS AND EVIDENCE}

Our discussion to this point has been primarily theoretical. Indeed, most of the influential contributions to the study of organizational governance have been theoretical, rather than empirical or applied. Nonetheless, a substantial body of applied and empirical literature, particularly in the economic theory of the firm, industrial economics, and business history, has emerged over the last three decades. Empirical work on organizational boundaries began to appear in the 1970s and 1980s with important papers on vertical integration and corporate diversification, and a literature on incentive contracting (in sharecropping and land tenure and, somewhat later, managerial pay) emerged around the same time. Other issues that have been studied extensively over the last three decades include marketing and distribution arrangements, long-term commercial contracts, complex "hybrid" arrangements such as franchise contracts, networks, and alliances, the multinational corporation, transfer pricing, licensing and leasing, and other organizational relationships. We discuss some examples below.

Unfortunately, governance and related organizational and managerial issues are more difficult to study, empirically, than prices and quantities, demographic trends, election results, and other issues of interest to empirical social scientists. We typically do not observe organizational characteristics directly, but must infer them from current and past behavior. There is little secondary data on governance (with the exception of merger and acquisition information and some related corporate governance statistics). Much of the early work thus focused on in-depth, quantitative or qualitative case studies (Williamson, 1976; Armour and Teece, 1978; Masten, 1984; Joskow, 1987, 1988b, 1990), historical narratives (Chandler, 1962, 1977), and multi-industry studies using qualitative proxies for organizational structure (Harris, 1983; Hoskisson and Galbraith, 1985; Steer and Cable, 1987; Hill, 1988). More recently, the literature has expanded to include larger samples and more sophisticated econometric techniques.

The empirical literature is broadly corroborative of the predictions and implications of the main strands of research in organizational governance, with important exceptions as described below. For the most part, empirical studies have been used to illustrate, rather than test, the core theories and doctrines of the nexus-of-contracts, agency-theoretic, and incomplete-contracting approaches to organizational governance, structure, and strategy. Consider examples from the literatures on organizational boundaries, mergers and acquisitions, diversification, the internal structure of the firm, antitrust and regulation, and public bureaucracies. 


\section{Organizational Boundaries}

One of the earliest issues studied by organizational economists was the vertical boundary of the firm or the "make-or-buy decision" (Klein, 2005). Nexus-of-contracts and agency theories, as explained above, have little to say about firm boundaries, regarding asset ownership as a legal, rather than economic, distinction. Incomplete contracting theories, however, have placed particular emphasis on boundaries, particularly vertical boundaries. Indeed, vertical integration is usually described as the "paradigm problem" of Williamson's transaction cost economics.

Vertical coordination, in Williamson's approach, is seen primarily as a means of safeguarding relationship-specific investments. The rents accruing to these investments can be secured through vertical integration, in which joint ownership eliminates any adversarial interests. Less extreme options include long-term contracts, partial ownership, or agreements for both parties to invest in offsetting relationship-specific investments. According to transaction cost theory, parties tend to choose the governance structure that best controls the underinvestment problem, given the particulars of the relationship, measured by asset specificity, uncertainty, and frequency. Hence important early studies (Armour and Teece, 1978; Masten, 1984; Joskow, 1987, 1988b) modeled organizational form as a function of these attributes, looking to see if asset specificity, for example, was a statistically significant determinant of in-house versus outsourced procurement or a contractual attribute such as duration. Most of the literature, summarized and critiqued by Joskow (1988a), Masten (1994), Shelanski and Klein (1995), Klein (2005), and Macher and Richman (2006), finds evidence to support such relationships, leading Williamson to brand transaction cost economics "an empirical success story."

Some problems remain, however. David and Han (2004) and Carter and Hodgson (2006) think the empirical transaction-cost literature has been interpreted too charitably. Klein (2005) notes several drawbacks of the most commonly used models: (1) key variables are inconsistently defined and measured; (2) asset specificity is a sufficient explanation for tight vertical coordination (vertical integration or long-term contractual relationships), but it may not be necessary; (3) many studies are consistent with TCE, but do not discriminate against TCE and rival explanations; and (4) most studies establish correlations, but not causal relations between transactional attributes and organizational form.

Besides the choice among discrete organizational modes such as vertical integration, spotmarket exchange, and intermediate or "hybrid" forms of organization, the characteristics of par- 
ticular contractual relationships - duration, completeness, complexity, and other attributes - have been examined in detail. For example, an influential series of papers by Joskow $(1985,1987$, 1988b, 1990) focuses on duration and price-adjustment provisions in agreements between coal suppliers and coal-burning electrical plants. He examined a large sample of coal contracts and found that contracts tended to be longer, all else equal, when relationship-specific investments (here, site specificity and dedicated assets) are at stake. Crocker and Masten (1988) find the same result for the natural gas industry. More generally, they argue that efficient contract duration depends on the costs of contracting; contract terms become shorter, for example, as uncertainty increases.

Another important contractual dimension is incompleteness. The transaction cost approach holds that all complex contracts are necessarily incomplete; otherwise, why would specialized governance arrangements be necessary? But the degree of incompleteness - for instance, the extent to which renegotiation procedures are specified - is endogenous. Research has identified uncertainty, expectations about other parties' preferences based on prior dealings, beliefs about the effectiveness of court enforcement, and other transactional and environmental attributes as determinants of completeness (Crocker and Masten, 1991; Crocker and Reynolds, 1993; Saussier, 2000). Besides duration, price-adjustment provisions, and completeness, other contractual practices such as "take-or-pay" and exclusive-dealing provisions have been analyzed with transaction cost reasoning.

More recently, empirical researchers begun examining the emergence of more complex forms of organization such as partial ownership agreements, franchises, networks, alliances, relational contracts, and other combinations. Ménard (2004) provides several examples of hybrids and explains what functions they perform. Under franchising, the franchisor's brand-name capital is a valuable asset (though it may or may not be specific to particular franchisees); franchise contracts allow the franchisor to leverage this asset while retaining the high-powered incentives the franchisee would lose under vertical integration. An extensive empirical literature has tried to explain pricing arrangements such as license fees and royalty rates (Lafontaine, 1992; Bercovitz, 1999), along with specific franchising provisions such as formal procedural rules, standardization of inputs and outputs, and centralization of core functions like training and information technology (Dnes, 1996; Lafontaine and Slade, 1997; Lafontaine and Raynaud, 2002), using 
transaction cost and agency theory. Still, important puzzles remain; one is the coexistence of franchised and company-owned stores within the same brand.

Firms may also organize themselves into networks, groups that pool resources but often rely on relational contracts, rather than formal written agreements, to coordinate their behavior. Networks are particularly important in agriculture, where an increasing emphasis on quality control necessitates tight coordination among members of the vertical production process (Ménard 1996). Formal ties can also help firms realize the agglomeration economies that result from knowledge and other geographic spillovers (Porter 2000). Transaction cost reasoning helps explain the observed variety of network structures (Ménard 1996) as well as the specific contractual arrangements used by network (or formal alliance) partners to protect specific investments (Oxley 1997). Still, we know relatively little about the efficiency of networks and alliances relative to integrated firms and the rules network members use to govern the returns to shared resources. Another important question is whether networks are a stable mode of organization, or a transitional form, eventually giving way to more consolidated (or fragmented) structures (Ménard and Klein 2004).

Moreover, contractual relations need not be fully formal and explicit; trading arrangements are often governed by less formal, relational norms. Palay $(1984,1985)$ studies the role of informal, legally unenforceable agreements between rail freight carriers and shippers. Shipment of items like automobile parts and chemicals, for example, requires specially designed rail cars and equipment that cannot be easily redeployed for other uses. Because vertical integration was prohibited by regulation, informal agreements emerged to protect these relationship specific investments. Baker, Gibbons, and Murphy (2001) show, more generally, how relational contractingboth between and within firms - differs from formal contracting. Relational contracts have the advantage that outcomes need not be verifiable to third parties, such as courts, to limit parties' incentives to behave opportunistically. On the other hand, the absence of third-party participation means that such agreements must be self-enforcing. Heide and John's (1992) study of buyersupplier relations finds that relational norms often substitute for vertical integration as a means of protecting specific assets; Anderson and Weitz (1992) and Brown, Dev, and Lee (2000) show that such norms are also important in marketing. 


\section{The Internal Structure of the Firm}

In contrast to the literature on firm boundaries (particularly vertical boundaries), there is very little systematic empirical evidence on the performance effects of internal organizational structure. A modest literature emerged in the late 1970s attempting to classify firms according to their organizational structure and see how organizational structure affects profitability and market value. The inspiration was Chandler's work on the emergence of the multidivisional, or "Mform," corporation. Chandler's pathbreaking studies of the emergence of the multidivisional or "M-form" corporation, Strategy and Structure (1962) and The Visible Hand (1977), directly inspired Williamson's work on the organization of hierarchy. ${ }^{25}$ The M-form's distinctive feature is the separation of strategic and operating responsibilities. Unlike the older, unitary or "U-form" firm, in which activities are divisionalized according to function (production, sales, marketing, research, and so on), the M-form firm divides its activities into business units according to product line or geographic area. Each business unit is a semi-autonomous profit center with its own functional subdivisions (production, sales, marketing). The chief advantage of the M-form, relative to the U-form, organization is the combination of local, decentralized decision making (for the firm's day-to-day activities) with centralized, long-term strategic planning. When operational decisions are made at the divisional level, the central headquarters of the firm (HQ) is freed to focus on the allocation and governance of resources among the divisions. This analysis gives rise to what Williamson (1975, p. 150) terms the "M-form hypothesis": "The organization and operation of the large enterprise along the lines of the M-form favors . . . behavior more nearly associated with the neoclassical profit maximization hypothesis than does the U-form organizational alternative."

Empirical support for the M-form hypothesis is mixed. Steer and Cable (1978), Teece (1981), and Hill (1985) find strong evidence of superior M-Form performance, while Armour and Teece (1978), Thompson (1981), and Harris (1983) find evidence that is weaker yet consistent with the

\footnotetext{
${ }^{25}$ Chandler, however, once an enthusiastic supporter of the transaction cost approach, has recently endorsed a more explicitly knowledge-based view. In a 1992 paper, "Organizational Capabilities and the Theory of the Firm," Chandler argues that it is "the specific nature of the firm's facilities and skills [that is] the most significant factor in determining what will be done in the firm and what by the market" (p. 86) — essentially the argument made by capabilities theorists such as Richardson (1972). An application of this argument to a set of concrete historical episodes is done in Langlois and Robertson's "Explaining Vertical Integration: Lessons from the American Automobile Industry" (1989). Somewhat in contrast to Chandler and Langlois and Robertson's reasoning, Raff and Temin in "Business History and Recent Economic Theory: Imperfect Information, Incentives, and the Internal Organization of Firms" (1991) suggest that recent contract theory is actually helpful to the business historian.
} 
hypothesis. Cable and Dirrheimer (1983) and Cable and Yasuki (1984), studying German and Japan, respectively, find no evidence that M-form firms outperformed their non-M-form counterparts (though the capital markets there are very different from those in the U.S. and Britain).

More recently, researchers have moved away from using such qualitative classifications in favor of indirect, but objective, proxies for organizational structure. The "diversification discount" literature in empirical corporate finance assumes that organizational form is correlated with the number of industry segments, the distribution of activities across industries, or some measure of relatedness. (Among the many papers in this literature, the best known are Lang and Stulz, 1994; Berger and Ofek, 1995; Campa and Kedia, 2003, Chevalier, 2004). A few papers try to infer organizational form from past activities, such as prior acquisitions (Hubbard and Palia, 1999; Klein, 2001). More direct measures include segment or subsidiary counts within a single industry (Sanzhar, 2006, Klein and Saidenberg, 2007), the ratio of administrative staff to total employees (Zhang, 2005), the number of positions reporting directly to the CEO (Rajan and Wulf, 2003), and the average number of management levels between the CEO and division managers (Rajan and Wulf, 2003).

\section{M\&A and Diversification}

Organizational economics also has important implications for mergers, divestitures, and restructurings as mechanisms for changing firm boundaries and governance structure, as well as implications for diversification and diversification's impact on firm performance, key issues in corporate finance as well as strategic management. The choice between acquisition and internal growth can be modeled as a transaction cost problem, and the vast theoretical and empirical literature on the gains from $M \& A$ and corporate reorganizations can be viewed as applications of the economic approach to organizational governance (mostly, agency theory). The literature on boundaries goes far beyond textbook explanations for economies of scope in production. As Teece $(1980,1982)$ pointed out, scope economies imply joint production, not integration; absent transactional difficulties, two separate firms could simply contract to share the inputs, facilities, or whatever accounts for the relevant scope economies. If they do not, it must be because the costs of writing or enforcing such a contract are greater than the benefits from joint production. 
Diversification also has little to do with risk reduction, as investors can reduce firm-specific risk by holding diversified portfolios, consisting of shares in a variety of single-product firms. ${ }^{26}$

Williamson (1975: 155-75) offers an account of the multi-product firm based on intra-firm capital allocation. In his theory, diversified firms arise when limits in the capital market permit internal management to allocate and manage funds more efficiently than the external capital market. These efficiencies may come from several sources. First, the corporate office typically has access to information unavailable to external parties, which it extracts through its own internal auditing and reporting procedures (Williamson, 1975, pp. 145-47). Second, managers inside the firm may also be more willing to reveal information to the corporate office than to outsiders, since revealing the same information to the capital market would also reveal it to rival firms, potentially hurting the firm's competitive position. Third, the corporate office can intervene selectively, making marginal changes to divisional operating procedures, whereas the external market can discipline a division only by raising or lowering the share price of the entire firm. Fourth, the corporate office has residual rights of control that providers of outside finance do not have, making it easier to redeploy the assets of poorly performing divisions (Gertner, Scharfstein, and Stein, 1994). More generally, these control rights allow headquarters to add value by engaging in "winner picking" among competing projects when credit to the firm as a whole is constrained (Stein, 1997). Fifth, the internal capital market may react more "rationally" to new information: those who dispense the funds need only take into account their own expectations about the returns to a particular investment, and not their expectations about other investors' expectations, eliminating speculative bubbles or waves.

On the other hand, some writers argue that cross-subsidization is harmful, leading to rent seeking by divisional managers (Scharfstein and Stein, 2000), bargaining problems within the firm (Rajan, Servaes, and Zingales, 2000) or bureaucratic rigidity (Shin and Stulz, 1998). Intrafirm resource allocation can be "sticky," and resources may not flow to their highest-valued uses.

Empirical evidence on the relationship between diversification and performance is mixed. Influential studies by Lang and Stulz (1994), Berger and Ofek (1995), and Servaes (1996) found that multi-segment firms traded at a discount relative to more specialized firms, or to portfolios

\footnotetext{
${ }^{26}$ Moreover, risk pooling at the firm level should be more costly than risk pooling at the level of the individual investor, since the transaction costs of buying or selling stock are presumably lower than the transaction costs of adding or liquidating a division (Williamson, 1975, p. 144). Diversification to reduce risk only benefits managers, who can reduce their own "employment risk" at the expense of the value of the firm (Amihud and Lev, 1981).
} 
of nondiversified firms from the diversified firm's industries. More recently, however, Chevalier (2000), Villalonga (2000), Campa and Kedia (2002), and Graham, Lemmon, and Wolf (2002) argue that diversified firms trade at a discount not because diversification destroys value, but because undervalued firms tend to diversify. Diversification is endogenous and the same factors that cause firms to be undervalued may also cause them to diversify. ${ }^{27}$ Even the conventional wisdom on the 1960s has been challenged, with Matsusaka (1993), Hubbard and Palia (1999), and Klein (2001) finding evidence for efficiency gains from some conglomerate mergers.

Note that while the theory of merger and acquisition deals with changes in organizational boundaries, economics is only beginning to move away from static, equilibrium models of firm and industry structure to embrace dynamic, evolutionary, and disequilibrium approaches. Concepts of Schumpeterian competition, dynamic capabilities, industry evolution, and entrepreneurship are getting increasing attention in the theoretical literature. The empirical literature, however, has not quite kept pace. Cross-sectional studies, based on comparative-static models, are still common in resource-based, agency-theoretic, and transaction-cost approaches to organizational strategy and organization. Much effort has gone into analyzing the determinants and performance effects of firm boundaries, strategy, and internal structure. Yet we know considerably less about changes in firm characteristics and behavior.

Casual empiricism suggests that rapid change is the norm in most industries. Firms are founded and then dissolved; previously acquired assets are divested; contracts are renegotiated; existing activities are scaled back; industries are exited. Data from the US Small Business Administration show that about half of all new businesses fail within the first four years. Ravenscraft and Scherer (1987) found that nearly one-third of all acquisitions during the 1960s and 1970s were eventually divested. Kaplan and Weisbach (1992) studied 217 large acquisitions completed between 1971 and 1982 and found that 44 percent had been divested by 1989. Klein and Klein (2005) studied 222 pairs of firms that merged during the 1977-83 period and found that 30 percent had been divested by 1995. During the 1980s and 1990s many diversified firms were restructured, refocused, and "disaggregated" (Hesterly and Zenger, 1997). Applied work in

\footnotetext{
${ }^{27}$ There are also important data and measurement problems. Most studies use Tobin's $q$ to measure divisional investment opportunities, but it is marginal $q$ - which may not be closely correlated with observable $q$ - that drives investment (Whited, 2001). SIC codes are also typically used to measure diversification and to identify industries, but the SIC system contains significant errors (Kahle and Walkling, 1996) and cannot reliably distinguish between related and unrelated activities (Teece, Dosi, Rumelt, and Winter, 1994; Lien and Klein, 2005).
} 
organizational governance is only beginning to reconcile this evidence with established theories of organization and strategy.

\section{Antitrust and Regulation}

Organizational economics, particularly in its transaction-cost incarnation, has obvious implications for antitrust, regulation, and other aspects of government policy toward business. Indeed, the subtitle of Williamson's 1975 book Markets and Hierarchies is “Analysis and Antitrust Implications," and significant parts of his work taken issue with what he calls the "inhospitality tradition" in antitrust — that is, the notion characteristic of antitrust thinking in the 1960s in the US and until recently in the European Union that firms engaged in non-standard business practices like vertical integration, customer and territorial restrictions, tie-ins, franchising, and so on, must be seeking monopoly gains. Of course, Williamson's argument was that many of such nonstandard practices in actuality enhanced efficiency by economizing with transaction costs. Antitrust practice is now, generally speaking, very lax on vertical arrangements (the typical exception being resale price maintenance), and it is quite arguable that much of the changed antitrust climate in this regard can be traced to the rather general acceptance in the economics profession of transaction cost (and contract theory) arguments concerning the efficiency properties of such arrangements.

As Shelanski and Klein (1995) explain, transaction cost economics in particular, has actual or direct implications for other contracting practices and regulations. They invoke Barker and Chapman's (1989) argument that that closed-shop agreements in labor markets may serve to protect workers' job-specific training rather than to exploit a monopoly position. They also point to studies of optimal contract design, notably Crocker and Reynolds's (1993) examination of Air Force procurement contracts as guides to public policy toward government purchases of goods and services.

\section{Public Bureaucracies}

Organizational governance, as defined in this chapter, refers primarily to arrangements that govern private, profit-seeking enterprises. While the literature on the organization and governance of non-market institutions such as public bureaucracies, non-profit institutions, religious bodies, and the like has evolved largely independently of organizational economics, there has been important cross-fertilization between these fields. Much of the modern literature in "posi- 
tive political economy," for example, takes models developed in the economic analysis of organization and applies them to non-market settings (Moe, 1984, 1990; Shepsle and Weingast, 1987; North and Weingast, 1989; Weingast, 1997). Building on the core insights from theories of rentseeking and public choice (Downs, 1965; Tullock, 1967; Niskanen, 1971), this literature seeks to explain how political actors craft governance structures, or institutions, to facilitate efficient production and exchange of political goods and services. These studies are part of the "rationalchoice" tradition in political science, broadly speaking, but focus on coalition formation, the role of reputation, formal and informal contracts (i.e., constitutions), and similar structures as means of organizational governance.

\section{CRITIQUES AND DISCUSSION}

\section{Debate on Organizational Economics}

Ever since its take-off period in the mid-nineteen seventies, organizational economics has been subject to intense debate. Much debate has been an internal one between scholars who are within or at least stay relatively close to the economic mainstream (e.g., Dow 1987; Hart 1995; Kreps 1996; Furubotn and Richter 1997; Maskin and Tirole 1999; Foss and Foss 2000; Furubotn 2002; McLeod 2002). However, there are also many external critiques that is represented by from sociologists, heterodox economists of various stripes, and management scholars. Williamsonian transaction cost economics in particular has been a favorite Prügelknabe for about three decades (Hodgson, 1989; Perrow, 2002), but agency theory has also drawn a fair amount of fire (Donaldson, 1996). Thus, early critics argued that transaction cost neglected power relations (Perrow ,1986), as well trust and other forms of social embeddedness (Granovetter 1985), and paid too little attention to evolutionary considerations, including Knightian uncertainty and market processes (Langlois, 1984). Such critiques have been echoed and refined in numerous contributions until this day. Criticizing organizational economics is still a thriving industry, populated by sociologists (Freeland,2002), heterodox economists (e.g., Hodgson, 1998; Langlois and Foss 1999; Hodgson, 1998; Loasby, 1999; Witt, 1999; Dosi and Marengo, 2000), and, increasingly, management scholars (e.g., Kogut and Zander, 1992; Ghoshal and Moran, 1996; Ferraro, Pfeffer, and Sutton, 2005). Critics have also questioned the empirical evidence supporting organizational economics (Hodgson year...). It often seems that many of the characteristics that the critics focus in on are not really particular to organizational economics, but are characteristic features of con- 
temporary (game-theoretic) microeconomics. ${ }^{28}$ However, in the following these characteristics and features are discussed as they apply to organizational governance.

\section{Cognition}

Formal economics typically assumes that agents hold the same, correct model of the world and that model does not change. This is also the case of the formal manifestations of organizational economics. More precisely, these assumptions are built into formal contract theory through the assumption that payoffs, strategies, and the like are common knowledge. These assumptions are clearly at variance with the notion of bounded rationality (Simon, 1955), and in formal organizational economics bounded rationality is almost entirely neglected (but see, e.g., Mookherjee, 1998). In contrast, bounded rationality is often invoked in Williamson's $(1985,1996)$ less formalized work, but its role here is mainly to explain why contracts are incomplete. The reason is presumably that the theory is taken up with comparative institutional exercises, focusing on transaction cost economizing, and hence has no room for the process aspects introduced by more substantive notions of bounded rationality (e.g., Furubotn 2002). ${ }^{29}$

In contrast, bounded rationality has long been a central assumption in organization theory (e.g., March and Simon,1958; Cyert and March,1963; Grandori, 2001). In fact, recent critics of organizational have drawn explicitly on these older sources to develop alternative, evolutionary views emphasizing the role of bounded rationality in problem-solving, and the role of firms as cognitive structures around such problem-solving efforts (e.g., Dosi and Marengo, 1994). Other critics, also echoing behavioral organization theory, argue that a key characteristic of firms is that they tend to shape employee cognition (Kogut and Zander 1996; Hodgson 1998; Witt 1999). For example, starting with social learning theory, Witt (1999) argues that individual cognitive frames are socially shaped and that firms can accomplish such shaping.

\footnotetext{
${ }^{28}$ However, a different interpretation is possible: What (at least some) critics protest is the use of tools that may well be appropriate for the analysis of market exchange to analyze firm organization. Thus, while some critics may balk at methodological individualism and rational-choice methodology in general, they are likely to find such assumptions particularly objectionable when they are applied to the theory of the firm. In much of the critical literature, firms (particularly three or four decades back) are often portrayed in rosy terms as "mini-societies" (Freeland 2002) of "communities" (Ferraro, Pfeffer, and Sutton, 2005) that provide "identity" (Kogut and Zander 1996), "higherorder organizing principles" (Kogut and Zander 1992), trust relations (Ghoshal and Moran 1996), and collective learning (Hodgson 1998) that, purportedly, "atomistic" markets cannot provide.

${ }^{29}$ Dow (1987) argues that it is inconsistent to invoke bounded rationality as a necessary assumption in the analysis of contracts and governance structures, and then assume that substantively rational choices can be made with respect to the contracts and governance structures (that are imperfect because of bounded rationality). See also Kreps (1996) for a similar point.
} 
Few economists of organization have reacted to the above critiques, arguably because taking these critiques seriously means questioning fundamental tenets of mainstream economic modelling; thus, bounded rationality questions, for example, subjective expected utility theory, the independence of payoff utilities, the irrelevance of labeling, and common prior beliefs (Camerer, 1998). However, a handful of contributions, mainly to contract theory, do try to model agents that are boundedly rational in a more substantive sense. For example, Mookerjee (1998) shows how ambiguity may lead to incomplete contracting; Carmichael and McLeod (2003) show that if boundedly rational agents care about sunk costs, this may solve the hold-up problem. There are various problems with such approaches. Notably, there may be too many "degrees of freedom," in the sense that virtually any cognitive bias may be thrown into a standard contracting model, thus producing a nonstandard result. Moreover, how does the theorist decide which manifestation of bounded rationality to model? The danger is that one ends up with a string of unconnected and extreme partial models with no apparent connection to empirical reality.

\section{Motivation}

In critiques of organizational economics, the notion of opportunism seems to be the favorite bête-noire. The critique takes various forms. Thus, some may dismiss the relevance of opportunism is dismissed by pointing to the low frequency with which opportunistic action can be observed, an argument that misunderstands the counterfactual nature of reasoning in the theory of the firm: Opportunistic behavior is seldom observed because governance structures are chosen to mitigate opportunism. According to a more recent argument, the primary problem with the treatment of motivation in organizational economics is not opportunism per se, but rather that all motivation is of the "extrinsic" type (Ghoshal and Moran, 1996; Osterloh and Frey, 2000). In other words, all behavior is understood in terms of encouragement from an external force, such as the expectance of a monetary reward. (In contrast, when "intrinsically" motivated, individuals wish to undertake a task for its own sake). Ghoshal and Moran (1996) argue that organizational economics misconstrues the causal relation between motivation (e.g., the tendency to shirk) and the surrounding environment (the type of governance structure in place). "Hierarchical" controls, they state, reduce organizational loyalty and thus increase shirking. Williamson's approach becomes a "self-fulfilling prophecy," and is therefore "bad for practice." Lindenberg (2003) makes use of psychological notions of framing to develop a subtle argument that managers by their actions, whether consciously or unconsciously, send behavioral signals to employees that induce 
specific cognitive frames in the minds. In turn such frames influence whether employee motivation lies more towards the extrinsic or the intrinsic pole of the motivational spectrum.

These arguments do not necessarily deny the reality of opportunism, moral hazard, and so on, but assert that there are other, more appropriate ways to handle these problems than providing monetary incentives, sanctions, and monitoring. The arguments are often based on social psychological research (Deci and Ryan, 1985) and on experimental economics (e.g., Fehr and Gächter, 2000). It is characteristic of much of the literature that the social psychology research that is cited is very seldom questioned. However, we believe that the jury is still out on such crucial issues as the pervasiveness, seriousness and reality of motivation crowding out (Deci and Ryan, 1985). Still, working, working with alternative motivational assumptions may be a fruitful way forward, and arguably one that may be more fruitful than working with alternative cognitive assumptions: It seems easier to doctor utility functions than cognitive assumptions. Moreover, the implications for economic organization may also seem more immediate (see Lazear 1991; Fehr and Gächter 2000 for concrete examples).

\section{Everything Is Given}

A major problem with modern economic theories of the firm is that they ignore the entrepreneur (Furubotn, 2002; Foss and Klein, 2005). Thus, Furubotn (2002: 72-3) points out that "profit is always in the background of TCE analysis because it is impossible to say whether a particular action (and contractual arrangement) undertaken by the firm is desirable or not purely on the basis of the costs of transacting. . . . There is reason, then, to give greater consideration to the question of how profits are generated." And this leads to the theory of entrepreneurship. However, in organizational economics reference to entrepreneurship is passing at best. Still, various attempts to put entrepreneurship into organizational economics do exist (e.g., Casson, 1997; Foss and Klein, 2005). For example, starting from a notion of entrepreneurship as judgmental decision-making under conditions of uncertainty that is hard to contract, Foss and Klein (2005) establishes a link to asset ownership and the start-up of a firm. In this approach, resource uses are not data, but are created as entrepreneurs envision new ways of using assets to produce goods. The entrepreneur's decision problem is aggravated by the fact that capital assets are heterogeneous, and it is not immediately obvious how they should be combined. Asset ownership facilitates experimenting entrepreneurship: acquiring a bundle of property rights is a low cost means of carrying out commercial experimentation. The problem with such ideas is that they lie fundamentally outside the standard constrained optimiza- 
tion framework and are inherently difficult to model mathematically. Modern economists are reluctant to appreciate ideas that are not expressed in the familiar formal language.

\section{Process Issues}

Many critics have taken issue with the presumed ahistorical, non-processual nature of organizational economics. One aspect of this is a neglect of path dependence. According to Winter (1991: 192):

In the evolutionary view-perhaps in contrast to the transaction cost view-the size of a large firm at a particular time is not to be understood as the solution to some organizational problem. General Motors does not sit atop the Fortune 500 ... because some set of contemporary cost minimization imperatives (technological or organizational) require a certain chunk of the U.S. economy to be organized in this manner. Its position at the top reflects the cumulative effect of a long string of happenings stretching back into the past."

It is correct that organizational economics has largely neglected how the governance of a particular transaction may depend on how previous transactions were governed. However, if such path dependence is actually present (what Argyres and Liebeskind [1999] call "governance inseparability"), firms may rationally rely on governance structures that appear inefficient at a particular time, but which make sense as part of a longer-term process. Changes in governance structure affect not only the transaction in question, but the entire temporal sequence of transactions. This may make organizational form appear more "sticky" than it really is. A partial response to this is Williamson's (1996) notion of remediableness. The outcome of a path-dependent process is suboptimal, he argues, only if it is remediable - that is, an alternative outcome can be implemented with net gains. Merely pointing to a hypothetical superior outcome, if it not attainable, does not establish suboptimality. Thus, a governance structure or contractual arrangement "for which no superior feasible alternative can be described and implemented with expected net gains is presumed to be efficient" (Williamson 1996: 7).

A related process issue turns on the explanation of economic organization in terms of efficiency that characterizes organizational economics. has been one of the most frequently criticized characteristics of the theory of the firm: Assuming that agents can figure out the efficient organizational arrangements seems to collide with the assumption of bounded rationality (Dow 1987; Furubotn 2002). Presumably in response to this problem, early work in the theory of the firm often explicitly assumed that market forces work to cause an "efficient sort" between trans- 
actions and governance structures, an assumption that is not in general tenable. While appealing to market selection, Williamson (1988: 174) also clearly recognizes that the process of transaction cost economizing is not automatic. Still, he maintains that the efficiency presumption is reasonable, offering the argument that inefficient governance arrangements will tend to be discovered and undone. ${ }^{30}$ Clearly, this assumption is not an innocuous one. It is in fact a key underlying assumption in virtually all empirical work in the theory of the firm. A general problem with the empirical literature on organizational form is that we usually observe only the business arrangements actually chosen. However, if these arrangements are presumed to be efficient, then we can draw inferences about the appropriate alignment between transactional characteristics and organizational form simply by observing what firms do. The problem is that the efficiency assumption has always been taken as an essential, but untested, background assumption.

\section{Reflexivity}

Ferraro, Pfeffer and Sutton (2005; also see Ghoshal, 2006) build from a strong social constructionist position to argue that the language and assumptions of social science theories strongly affect, or even determine, much of what individuals do, experience, and think. Their paper may be seen as a generalization of arguments in Ghoshal and Moran (1996), and like these writers, Ferraro, Pfeffer, and Sutton (2005) are very strongly critical of organizational economics. In short, they argue that a self-fulfilling prophecy is created through (negative) theoretical assumptions about human motives and behavior being reinforced and diffused through the mechanisms of language, social norms, and institutional design; and in turn, the latter reflexively determines individual behavior in accordance with stated theoretical assumptions (also see Ghoshal, 2005: 77). The implication is that to the extent that economics successfully theorizes real mechanisms, particularly with respect to behavior, it is because much of social reality has already been fundamentally shaped by economics ideas and theories.

We have serious problems with these arguments concerning the performativity of organizational economics. Consider Ferraro, Pfeffer and Sutton's main example, the allegedly detrimental effect of the recent moves toward infusing hierarchies with market-like mechanisms which have resulted in downsizing and the "commodification" of employees. The driver of this, it seems, is

\footnotetext{
${ }^{30}$ Concerning vertical integration, for example, Williamson (1985: 119-20) writes that "backward integration that lacks a transaction cost rationale or serves no strategic purposes will presumably be recognized and will be undone," adding that mistakes will be corrected more quickly "if the firm is confronted with an active rivalry."
} 
solely the "rationalized institutional myth" (Meyer and Rowan, 1977) of the "market metaphor." However, there are strong reasons to believe that the infusion of markets into hierarchy is much more than a self-fulfilling rhetorical device with mostly negative consequences. Markets have so far consistently and for a very long time demonstrated a fabulous track record in economic history, which makes the ascription of "myth" to market performance inappropriate. Moreover, what has worked in economies at large may also work in smaller economies, such as firms (e.g., Zenger and Hesterly, 1997).

The last decades have indeed witnessed a strong tendency to "disaggregate" into smaller organizational units. Firm size appears to have decreased and firms are increasingly breaking up their internal organization into smaller molecular units with high-powered market-like incentives. This tendency has been facilitated by improvements in information technology, measurement methods and cost allocation that allow for better measurement of individual efforts and output, and which have prompted the adoption of smaller organizational units and for smaller firms (Zenger and Hesterly, 1997). Smaller organizations with more market-like mechanisms are better able to match incentives with effort (e.g., Alchian and Demsetz, 1972; Zenger, 1994). High-powered incentives thus are better infused into smaller organizations such as partnerships, professional services firms being the quintessential example (see further, Felin and Foss, 2007).

\section{Organizational Sociology}

Organizational sociologists (e.g., Perrow, 1986) have typically had rather limited patience with organizational economics. ${ }^{31}$ However, organizational sociology may be of considerable indirect relevance for a rational-choice approach to organizational governance, by pointing to explananda that have so far not been theorized in a rational-choice approach, and by pointing to other, potentially more fine-grained explanatory mechanisms (Buskens, Raub, and Snijders, 2003; Nooteboom and Six, 2003). Labor-market economist and agency theorist Robert Gibbons $(1999,2003,2005)$ has long advocated such a view. In particular, organizational economics treats the embeddedness of actions in relations and networks as a black box, summarizing it simply as "relational contracting." Organizational sociology research on embeddedness (e.g., Buskens, Raub, and Snijders, 2003) adds an essentially complementary view to organizational economics that, however, goes significantly beyond the micro-foundations of organizational

\footnotetext{
${ }^{31}$ The other side of the coin is that few rational-choice sociologists have been interested in organizational sociology; a notable exception is Lindenberg [e.g., 2003] ).
} 
economics by highlighting framing effects, the situational dependence of preference, and so on (see Lindenberg, 2003).

However, it remains that (non-rational-choice) organizational sociology and rational-choice approaches to organizational governance are direct theoretical competitors when they address similar explananda. For example, concerning inter-organizational relations and firm boundaries, resource-dependency theory (Pfeffer and Salancik, 1978) and transaction cost economics (Williamson, 1985) are direct competitors. And sociological new institutionalism (Meyer and Rowan, 1977) offer very different answers than economics-based new institutionalism (Williamson, 1985) concerning why specific organizational forms are adopted in a population of firms. Very different views of the rationale of incentives in organizations are forwarded (compare Pfeffer, Sutton and Ferraro [2005] and Zenger and Hesterly [1997]). And so on. In other words, we see very different theoretical mechanisms being put forward to explain the same phenomena, and so far no "meta" models have emerged that can express these different mechanisms in a unified language.

\section{CONCLUSION}

Despite continuing questions about the scope of the relevant theories, their robustness to alternative behavioral assumptions, the degree to which they are substitutes or complements, and related issues, the broad set of rational-choice approaches to organizational governance discussed here have proved highly successful in explaining what firms are, what firms do, and how firms are structured. Less is known about how firms change through time and how "soft" characteristics such as leadership, culture, and capabilities affect the performance of the firm. Still, modern theories of organizational governance have made considerable headway in shedding light on the core problems of firm organization and management.

As described above, the most common theories of organizational governance differ in many details. Still, they share important features: an emphasis on maximizing behavior, imperfect and incomplete information, costs of monitoring or costs of contracting, and the like. They share common roots in the explosion of "Coasian" approaches to economic organization that emerged in the mid 1970s. Is this a weakness? Almost two decades ago Paul Milgrom and John Roberts (1988b: 450) argued that the "incentive-based transaction costs theory has been made to carry too much of the weight of explanation in the theory of organizations," predicting that "competing 
and complementary theories" would emerge, "theories that are founded on economizing on bounded rationality and that pay more attention to changing technology and to evolutionary considerations." However, no serious competitors have emerged so far.

Why have behavioral, evolutionary, Austrian, and other "heterodox" approaches failed to make much headway? One possibility is that mainstream organizational economics is sufficiently successful that competitors have a hard time gaining a foothold. Still, as we have stressed throughout this chapter, many of the critiques do in fact point to weaknesses in the theory of the firm that should ideally be remedied. A further reason is that the critics tend to focus on phenomena that are difficult to model. Innovation, entrepreneurship, bounded rationality, learning, evolutionary processes, and differential capabilities are examples of such phenomena. The formal tools that can handle such phenomena may not exist to a sufficient extent have been developed. However, recent attempts to integrate entrepreneurship into the theory of the firm (Foss and Klein, 2005), to build bridges between the economic theory of the firm and theories of firm strategy and capabilities (Williamson, 1991; Nickerson and Vanden Bergh, 1999), and otherwise enhance approaches based on transaction cost suggest that organizational governance remains a rich field for further study. 


\section{REFERENCES}

Abell, Peter, ed. 1991. Rational Choice Theory. Aldershot: Edward Elgar.

Abell, Peter, Teppo Felin, and Nicolai Foss. 2007. "Building Foundations for the Routines, Capabilities, and Performance Links," Managerial and Decision Economics (forthcoming).

Aghion, Philippe and Jean Tirole. 1995. "Some Implications of Growth for Organizational Form and Ownership Structure," European Economic Review 39: 440-455.

Aghion, Philippe and Jean Tirole. 1997. "Formal and Real Authority in Organization," Journal of Political Economy 105: 1-29.

Akerlof, George. 1970. "The Market for Lemons: Quality Uncertainty and the Market Mechanism" Quarterly Journal of Economics 84: 488-500.

Alchian, Armen A. 1958. "Private Property and the Relative Cost of Tenure," in idem. 1977. Economic Forces at Work, Indianapolis: Liberty Press.

Alchian, Armen A. 1965. "Some Economics of Property Rights," in idem. 1977. Economic Forces at Work, Indianapolis: Liberty Press.

Alchian,Armen A. and Harold Demsetz. 1972. "Production, Information Costs, and Economic Organization," American Economic Review 62: 772-795.

Anderlini, Luca and Leonardo Felli. 2004. "Bounded Rationality and Incomplete Contracts," Research in Economics 58: 3-30.

Anderson, Erin. 1988. "Strategic Implications of Darwinian Economics for Selling Efficiency and Choice of Integrated or Independent Sales Forces," Management Science 34: 599-618.

Antle, Rick and Joel S. Demski. 1988. "The Controllability Principle in Responsibility Accounting," Accounting Review 63: 700-718.

Aoki, Masahiko. 1986. "Horizontal vs Vertical Information Structure of the Firm," American Economic Review 76: 971-983.

Argyres, Nicholas S. and Julia Porter Liebeskind. 1999. "Contractual Commitments, Bargaining Power, and Governance Inseparability: Incorporating History into Transaction Cost Theory," Academy of Management Review 24: 49-63.

Armour, Henry O., and David J. Teece. 1980. "Vertical Integration and Technological Innovation." Review of Economics and Statistics 62: 470-74.

Arrow, Kenneth. 1951. Social Choice and Individual Values. New York: Wiley.

Arrow, Kenneth J. 1971. Essays in the Theory of Risk-Bearing. Amsterdam: North-Holland.

Arrow, Kenneth J. 1974. The Limits of Organization, New York: W.W. Norton \& Co.

Arrow, Kenneth J. 1987. "Reflections on the Essays," in George Feiwel, ed. Arrow and the Foundations of Economic Policy, New York: New York University Press.

Bajari, Patrick, and Steven Tadelis. 2001. "Incentives versus Transactions Costs: A Theory of Procurement Contracts," RAND Journal of Economics 32: 387-407.

Baker, George, Robert Gibbons and Kevin J. Murphy. 1994. "Subjective Performance Measures in Optimal Incentive Contracts," Quarterly Journal of Economics 109: 1125-1156. 
Baker, George, Robert Gibbons and Kevin J. Murphy. 2002. "Relational Contracts and the Theory of the Firm," Quarterly Journal of Economics 117: 39-84.

Barker, George R., and Ralph B. Chapman. 1989. "Evaluating Labor Market Contracting and Regulation: A Transaction Costs Perspective with Particular Reference to New Zealand." Journal of Institutional and Theoretical Economics 145: 317-342.

Barney, Jay B. and William G. Ouchi, eds. 1988. Organizational Economics. San Francisco: Jossey-Bass Publishers.

Baron, J. and M. Hannan. 1994. "The Impact of Economics on Contemporary Sociology," Journal of Economic Literature, 32: 1111-1146.

Barzel, Yoram. 1997. Economic Analysis of Property Rights, 2nd ed., Cambridge: Cambridge University Press.

Barzel, Yoram, and Levis A. Kochin. 1992. "Ronald Coase on the Nature of Social Cost as a Key to the Problem of the Firm," Scandinavian Journal of Economics 94: 19-31.

Benabou, Roland and Jean Tirole. 2003. "Intrinsic and Extrinsic Motivation," Review of Economic Studies 70: 489-520.

Bercovitz, Janet E. L. 1999. Having It Their Way? The Franchising Decision and the Structure of Franchise Contracts. Ph.D. dissertation, Haas School of Business, University of California, Berkeley.

Berger, Philip G., and Eli Ofek. 1995. “Diversification's Effect on Firm Value.” Journal of Financial Economics 37: 39-65.

Berle, Adolph A. and Gardiner C. Means. 1932. The Modern Corporation and Private Property. New York: Macmillan.

Boerner, Christopher and Jeffrey Macher. 2003. "Transaction Cost Economics: An Assessment of Empirical Research in the Social Sciences," Georgetown University Working Paper.

Bolton, Patrick, and Mathias Dewatripont. 1994. "The Firm as a Communication Network," Quarterly Journal of Economics 115: 809-839.

Boulding, Kenneth E. 1942. "The Theory of the Firm in the Last Ten Years," American Economic Review 32: 791-802.

Bowles, Samuel. 2004. Microeconomics. Princeton: Princeton University Press.

Bowles, Samuel and Herbert Gintis. 1988. "Contested Exchange: Political Economy and Modern Economic Theory,” American Economic Review 78: 145-150.

Bradach, J.L. and R.G. Eccles. 1989. "Price, Authority and Trust: From Ideal Types to Plural Forms," Annual Review of Sociology 15: 97-118.

Brousseau, Eric and Jean-Michel Glachant, eds. 2002. The Economics of Contracts. Cambridge: Cambridge University Press.

Buchanan, James. 1979. What Should Economists Do? Indianapolis: Liberty Press.

Buckley, Peter J. and Jonathan Michie, eds. 1996. Firms, Organizations, and Contracts: A Reader in Industrial Organization. Oxford: Oxford University Press.

Buskens, Vincent, Werner Raub, and Chris Snijders. 2003. The Governance of Relations in Organizations and Markets. Research in the Sociology of Organizations 20: 1-380. 
Cable, John, and M. Dirrheimer. 1983. "Hierarchies and Markets: An Empirical Test of the Multidivisional Hypothesis in West Germany.” International Journal of Industrial Organization 1: 43-62.

Cable, John, and Hirohiko Yasuki. 1985. "Internal Organization, Business Groups, and Corporate Performance: An Empirical Test of the Multidivisional Hypothesis in Japan." International Journal of Industrial Organization 3: 421-438.

Camerer, Colin. 1998. "Behavioral Economics and Nonrational Organizational Decision Making," in Debating Rationality. Jennifer J. Halpern and Robert N. Stern, eds. Ithaca: Cornell University Press.

Campa, Jose Manuel, and Simi Kedia. 2002. "Explaining the Diversification Discount." Journal of Finance 57: 1731-1762.

Carter, Richard and Hodgson, Geoffrey M. 2006. "The Impact of Empirical Tests of Transaction Cost Economics on the Debate on the Nature of the Firm." Strategic Management Journal 27: 461-476.

Casson, Mark, ed. 1996. The Theory of the Firm. Cheltenham: Edward Elgar.

Casson, Mark. 1997. Information and Organization. Oxford: Oxford University Press.

Chamberlin, Edward. 1933. The Theory of Monopolistic Competition. 8th ed. Cambridge, Mass.: Harvard University Press.

Chandler, Alfred. D., Jr. 1962. Strategy and Structure: Chapters in the History of American Industrial Enterprise. Cambridge, Mass.: MIT Press.

Chandler, Alfred D., Jr. 1977. The Visible Hand: The Managerial Revolution in American Business. Cambridge, Mass.: Belknap Press.

Chandler, Alfred D., Jr. 1992. "Organizational Capabilities and the Theory of the Firm," Journal of Economic Perspectives 6: 79-100.

Charnes, A. and A.C. Stedry. 1966. "The Attainment of Organizational Goals," in J.R. Lawrence, ed. Operational Research and the Social Sciences. London: Tavistock Publications.

Cheung, Stephen S.N. 1983. "The Contractual Nature of the Firm," Journal of Law and Economics 26: 1-22.

Chevalier, Judith A. 2000. "Why Do Firms Undertake Diversifying Mergers? An Examination of the Investment Policies of Merging Firms." Working paper, Graduate School of Business, University of Chicago.

Coase, Ronald H. 1937. “The Nature of the Firm,” Economica (N.S.) 4: 386-405 (November).

Coase, Ronald H. 1960. "The Problem of Social Cost," Journal of Law and Economics 3: 1-44.

Coase, Ronald H. 1991a. "The Nature of the Firm: Origin, Meaning, Influence," in Oliver E. Williamson and Sidney G. Winter, eds. The Nature of the Firm. Oxford: Basil Blackwell.

Coase, Ronald H. 1991b. "The Institutional Structure of Production," in Oliver E. Williamson and Sidney G. Winter, eds. The Nature of the Firm. Oxford: Basil Blackwell.

Conlisk, John. 1996. "Why Bounded Rationality?,” Journal of Economic Literature 34: 669-700.

Conner, Kathleen and C.K. Prahalad. 1996. "A Resource-Based Theory of the Firm," Organization Science 7: 477-501. 
Cremer, Jacques. 1990. "Common Knowledge and the Coordination of Economic Activities," in Masahiko Aoki, Oliver E. Williamson and Bo Gustafsson, eds. 1990. The Firm as a Nexus of Treaties, London: Sage,

Crocker, Keith J. and Scott E. Masten. 1988. "Mitigating Contractual Hazards: Unilateral Options and Contract Length," RAND Journal of Economics 19: 327-343.

Crocker, Keith J., and Scott E. Masten. 1991. "Pretia Ex Machina? Prices and Process in LongTerm Contracts." Journal of Law and Economics 24: 69-99.

Crocker, Keith J. and Scott E. Masten. 1996. "Regulation and Administered Contracts Revisited," Journal of Regulatory Economics, 9: 5-39.

Crocker, Keith J., and Kenneth J. Reynolds. 1993. "The Efficiency of Incomplete Contracts: An Empirical Analysis of Air Force Engine Procurement." RAND Journal of Economics 24: 126-146.

Crozier, Michel. 1963. Le Phénomène Bureaucratique. Paris : Le Seuil

Cyert, Richard and James G. March. 1963. A Behavioral Theory of the Firm. Englewood Cliffs: Prentice-Hall.

David, R. J., and S. K. Han. 2004. "A Systematic Assessment of the Empirical Support for Transaction Cost Economics.” Strategic Management Journal 25: 39-58.

Debreu, Gerard. 1959. Theory of Value. New York: Wiley.

Deci, Edward L. and Richard M. Ryan. 1985. Intrinsic Motivation and Self-Determination in Human Behavior. New York: Plenum.

Demsetz, Harold. 1969. "Information and Efficiency: Another View," in idem. 1989. The Organization of Economic Activity: Efficiency, Competition and Policy. Oxford: Basil Blackwell.

Demsetz, Harold. 1988. "The Theory of the Firm Revisited,” Journal of Law, Economics, and Organization 4(1): 141-161.

Demsetz, Harold. 1995. The Economics of the Firm: Seven Critical Commentaries, Cambridge: Cambridge University Press.

Director, Aaron and Edward H. Levi. 1956. "Law and the Future: Trade Regulation," Northwestern University Law Review 51: 281-317.

Dnes, Anthony. 1996. "The Economic Analysis of Franchise Contracts.” Journal of Institutional and Theoretical Economics 152: 297-324.

Dosi, Giovanni and Luigi Marengo. 1994. "Some Elements of an Evolutionary Theory of Organizational Competences," in Richard W. Englander. Evolutionary Concepts in Contemporary Economics. Ann Arbor: University of Michigan Press.

Dow, Greg. 1987. "The Function of Authority in Transaction Cost Economics," Journal of Economic Behavior and Organization 8: 13-38.

Downs, Anthony. 1957. An Economic Theory of Democracy. New York: Harper and Row.

Downs, Anthony. 1967. Inside Bureaucracy. Boston: Little and Brown.

Dyck, Bruno. 1997. "Understanding Configuration and Transformation Through a Multiple Rationalities Approach,” Journal of Management Studies, 34: 793-823. 
Fama, Eugene. 1980. "Agency Problems and the Theory of the Firm," Journal of Political Economy, 88: 288-307.

Fama, Eugene and Michael Jensen. 1983. "Agency Problems and Residual Claims," Journal of Law and Economics 26: 327-49.

Fehr, Ernst and Simon Gächter. 2000. "Fairness and Retaliation: The Economics of Reciprocity," Journal of Economic. Perspectives 14: 159-182.

Felin, Teppo and Nicolai J. Foss. 2007. "Say It Isn't So! Social Reality, the Language of Economics, and the Limits to Reflexivity," Working Paper.

Ferraro, F., Pfeffer, Jeffrey, and Robert I. Sutton. 2005. "Economics Language and Assumptions: How Theories Can Become Self-fulfilling," Academy of Management Review, 30: 8-24.

Foss, Nicolai J. 1996. "Knowledge-Based Approaches to the Theory of the Firm: Some Critical Comments”. Organization Science 7: 470-476.

Foss, Nicolai J. 2002. "Coase vs. Hayek: Economic Organization in the Knowledge Economy," International Journal of the Economics of Busines 9: 9-36.

Foss, Nicolai J. 2003a. "Selective Intervention and Internal Hybrids: Interpreting and Learning from the Rise and Decline of the Oticon Spaghetti Organization." Organization Science 14: 331-349.

Foss, Nicolai J. 2003b. "Herbert Simon's Grand Theme in the Economics of Organization: "Much Cited and Little Used'," Journal of Economic Psychology 24: 245-264.

Foss, Kirsten and Nicolai Foss. 2000. "Theoretical Isolation in Contract Economics," (with Kirsten Foss), Journal of Economic Methodology 7: 313-339.

Foss, Kirsten, Nicolai Foss and José Vasquez-Vicente. 2006 “Tying the Manager's Hands: Credible Commitment and Firm Organization," Cambridge Journal of Economics, 30: 797-818.

Foss, Nicolai and Peter G. Klein. 2005. "Entrepreneuship and the Theory of the Firm: Any Gains From Trade?," in Handbook of Entrepreneurship: Disciplinary Perspectives. Rajshree Agarwal, Sharon A. Alvarez, and Olav Sorenson, eds. Boston: Kluwer.

Foss, Nicolai J. and Peter G. Klein. 2008. The Theory of the Firm and Its Critics: a Stocktaking and an Assessment" Eric Brousseau and Jean-Michel Glachant, eds. Handbook of New Institutional Economics. Cambridge: Cambridge University Press.

Foss, Nicolai and Keld Laursen. 2005. "Performance Pay, Delegation, and Multitasking Under Uncertainty and Innovativeness: an Empirical Investigation," Journal of Economic Behavior and Organization 58: 246-276.

Furubotn, Eirik. 2002. "Entrepreneurship, Transaction-Cost Economics, and the Design of Contracts," in The Economics of Contracts. Eric Brousseau and Jean-Michel Glachant, eds. Cambridge: Cambridge University Press.

Furubotn, Eirik G. and Rudolf Richter. 1997. Institutions and Economic Theory: The Contribution of the New Institutional Economics. Ann Arbor: The University of Michigan Press.

Ghoshal, Sumantra, and Peter Moran. 1996. "Bad for Practice: A Critique of the Transaction Cost Theory," Acad. Man. Rev., 21, pp.13-47. 
Gibbons, Robert S. 1999. “Taking Coase Seriously,” Administrative Science Quarterly, 44: 145157 ,

Gibbons, Robert S. 2003. "Team Theory, Garbage Cans, and Real Organizations: Some History and Prospects of Economic Research on Decision-Making in Organizations," Industrial and Corporate Change, 12: 753-787.

Gibbons, Robert S. 2005a. "What is Economic Sociology and Should Any Economist Care?," Journal of Economic Perspectives, 19: 3-7.

Gibbons, Robert S. 2005b. "Incentives Between Firms (and Within)," Management Science 51: $2-17$.

Gillespie, Richard. 1991. Manufacturing Knowledge: A History of the Hawthorne Experiments. Cambridge: Cambridge University Press.

Grandori, Anna. 1997. "Governance Structures, Coordination Mechanisms, and Cognitive Models," Journal of Management and Governance, 1: 29-47.

Grandori, Anna. 2001. Organization and Economic Behavior. London: Routledge.

Granovetter, Mark S. 1985. "Economic Action and Social Structure: The Problem of Embeddedness". American Journal of Sociology 91: 481-510.

Grossman, Sanford, and Oliver Hart. 1986. "The Costs and Benefits of Ownership: A Theory of Vertical Integration,” Journal of Political Economy 94: 691-719.

Guesnerie, Roger. 1994. "The Arrow-Debreu Paradigm Faced With Modern Theories of Contracting," in Lars Werin and Hans Wijkander. 1992. Contract Economics, Oxford: Blackwell.

Håkansson, Håkan and Ivan Snehota. 1990. "No Business is an Island: The Network Concept of Business Strategy," Scandinavian Journal of Management 5': 187-200.

Harris, Barry C. 1983. Organization: The Effect on Large Corporations. Ann Arbor, Mich.: UMI Research Press.

Hart, Oliver D. 1989. “An Economist's Perspective on the Theory of the Firm," Columbia Law Review 89(7): 1757-1774.

Hart, Oliver. 1990. "Is "Bounded Rationality" an Important Element of a Theory of Institutions?," Journal of Institutional and Theoretical Economics 16: 696-702.

Hart, Oliver. 1995. Firms, Contracts and Financial Structure. Oxford: Clarendon Press.

Hart, Oliver and Bengt Holmström. 1987. "The Theory of Contracts," in Truman F. Bewley. 1987. Advances in Economic Theory. Fifth World Congress. Cambridge: Cambridge University Press.

Hart, Oliver and John Moore. 1990. "Property Rights and the Nature of the Firm," Journal of Political Economy 98: 1119-1158.

Hart, Oliver and John Moore. 1999. "Foundations of Incomplete Contracts," Review of Economic Studies 66: 115-138.

Hart, Oliver and John Moore. 2007.

Hayek, Friedrich A. von. 1945. "The Use of Knowledge in Society," in idem. 1948. Individualism and Economic Order, Chicago: University of Chicago Press. 
Hayek, Friedrich A. von. 1973. Law, Legislation, and Liberty, Vol.1: Rules and Order. Chicago: University of Chicago Press.

Heide, J. B., and George John. 1988. "The Role of Dependence Balancing in Safeguarding Transaction-Specific Assets.” Journal of Marketing 52: 20-35.

Hermalin, Benjamin E. 1998. "Toward an Economic Theory of Leadership: Leading by Example,” American Economic Review 88: 1188-1206.

Hill, Charles W. L. 1985. "Internal Organization and Enterprise Performance: Some U.K. Evidence." Managerial and Decision Economics 6: 210-216.

Hill, Charles W. L. 1988. "Internal Capital Market Controls and Financial Performance in Multidivisional Firms.” Journal of Industrial Economics 37: 67-83.

Holmström, Bengt. 1979. "Moral Hazard and Observability," Bell Journal of Economics 10: 7491.

Holmström, Bengt. 1982. "Moral Hazard in Teams," Bell Journal of Economics 13: 324-340.

Holmström, Bengt. 1999. "The Firm as a Mini-Economy,” Journal of Law, Economics, and Organization

Holmström, Bengt and Paul Milgrom. 1991. "Multitask Principal-Agent Analyses: Incentive Contracts, Asset Ownership, and Job Design," Journal of Law, Economics, and Organization 7: 24-52.

Holmström, Bengt and Paul Milgrom. 1994. "The Firm as an Incentive System," American Economic Review 84: 972-991.

Holmström, Bengt, and Jean Tirole 1989. "The Theory of the Firm,” in Richard Schmalensee and Robert D. Willig 1989. Handbook of Industrial Organization, Vol. 1. Amsterdam: North-Holland.

Hoskisson, Robert E., and C. G. Galbraith. 1985. "The Effect of Quantum versus Incremental MForm Reorganization of Performance: A Time Series Exploration on Intervention Dynamics.” Journal of Management 11: 55-70.

Hubbard, Glenn R., and Darius Palia. 1999. "A Re-Examination of the Conglomerate Merger Wave in the 1960's: An Internal Capital Markets View.” Journal of Finance 54: 1131-1152.

Imai, K. and H. Itami. 1984. "Interpenetration of Firm and Market," International Journal of Industrial Organization 2: 285-310.

Jensen, Michael C. and William Meckling 1976. "The Theory of the Firm: Managerial Behavior, Agency Costs and Ownership Structure," Journal of Financial Economics 3: 305-360.

Jensen, Michael and William Meckling. 1992. "Specific and General Knowledge, and Organizational Structure," in Lars Werin and Hans Wijkander, eds. 1992. Contract Economics. Oxford: Basil Blackwell.

Jones, Benjamin F. and Benjamin A. Olken. 2005. "Do Leaders Matter? National Leadership and Growth Since World War II," Quarterly Journal of Economics 120(3): 835-864.

Joskow, Paul L. 1987. "Contract Duration and Relationship-Specific Investments: Empirical Evidence from Coal Markets.” American Economic Review 77: 168-85. 
Joskow, Paul L. 1988a. "Asset Specificity and the Structure of Vertical Relationships: Empirical Evidence." Journal of Law, Economics, and Organization 4: 95-117.

Joskow, Paul L. 1988b. "Price Adjustment in Long-Term Contracts: The Case of Coal." Journal of Law and Economics 31: 47-83.

Joskow, Paul L. 1990. "The Performance of Long-Term Contracts: Further Evidence from the Coal Markets." Rand Journal of Economics 21: 251-74.

Kaplan, Steven N., and Michael S. Weisbach. 1989. The Success of Acquisitions: Evidence from Divestitures. Journal of Finance 47: 107-138.

Klein, Benjamin. 1988. "Vertical Integration as Organization Ownership," Journal of Law, Economics, and Organization 4: 199-213

Klein, Benjamin, Robert G. Crawford, and Armen A. Alchian. 1978. "Vertical Integration, Appropriable Rents, and the Competitive Contracting Process," Journal of Law and Economics 21 (2): 297-326.

Klein, Benjamin and Keith B. Leffler. 1981. "The Role of Market Forces in Assuring Contractual Performance," Journal of Political Economy 89: 615-641.

Klein, Peter G. 2001. "Were the Acquisitive Conglomerates Inefficient?" RAND Journal of Economics 32: 745-761.

Klein, Peter G. 2005. “The Make-or-Buy Decision: Lessons from Empirical Studies.” In Claude E. Ménard and Mary M. Shirley, eds., Handbook of New Institutional Economics. New York: Springer, pp. 435-464.

Klein, Peter G., and Sandra K. Klein. 2005. "Are Divestitures Predictable? A Duration Analysis." Working Paper, Contracting and Organizations Research Institute, University of Missouri.

Klein, Peter G., and Marc R. Saidenberg, 2007. "Organizational Structure and the Diversification Discount: Evidence from Bank Holding Companies.” Working Paper, University of Missouri.

Knight, Frank H. 1921 [1965]. Risk, Uncertainty, and Profit. New York: Augustus M. Kelley.

Kreps, David M. 1990. "Corporate Culture and Economic Theory“, in James E. Alt and Kenneth Shepsle, eds. 1990. Perspectives on Positive Political Economy, Cambridge: Cambridge University Press

Kreps, David M. 1996. "Markets and Hierarchies and (Mathematical) Economic Theory," Industrial and Corporate Change 5: 561-596.

Laffont, Jean-Jacques and David Martimort. 2002. The Theory of Incentives: The PrincipalAgent Model. Princeton: Princeton University Press.

Lafontaine, Francine. 1992. "Agency Theory and Franchising: Some Empirical Results." RAND Journal of Economics 23: 263-283.

Lafontaine, Francine, and Emmanuel Raynaud. 2002. "The Role of Residual Claims and SelfEnforcement in Franchise Contracting." NBER Working Paper 8868.

Lafontaine, Francine and Margaret Slade. 2007. "Vertical Integration and Firm Boundaries: The Evidence," Journal of Economic Literature 45: 629-685. 
Lang, Larry H. P., and René M. Stulz. 1994. “Tobin's Q, Corporate Diversification, and Firm Performance." Journal of Political Economy 102: 1248-1280.

Langlois, Richard N. 1995. “Do Firms Plan?” Constitutional Political Economy 6: 247-261.

Langlois, Richard N. and Nicolai J. Foss. 1999. "Capabilities and Governance: The Rebirth of Production in the Theory of Economic Organization," Kyklos 52: 201-218.

Lawrence, Paul R. and Jay W. Lorsch. 1967. "Differentiation and Integration in Complex Organizations," Administrative Science Quarterly 12: 1-47.

Lawler, Edward J. 2002. "Micro Social Orders.” Social Psychology Quarterly. 65(1): 4-17.

Lazear, Edward P. 1991. "Labor Economics and the Psychology of Organizations," Journal of Economic Perspectives, 5: 89-110.

Lindenberg, Sigward. 2003. "The Cognitive Side of Governance," Research in the Sociology of Organizations 20: 47-76.

Macher, Jeffrey T. and B. Richman. 2006. "Transaction Cost Economics: An Assessment of Empirical Research in the Social Sciences.” Working paper, McDonough School of Business, Georgetown University.

Machlup, Fritz. 1967. "Theories of the Firm: Marginalist, Behavioral, Managerial," American Economic Review 57: 1-33.

MacLeod, William Bentley. 2002. "Complexity and Contract," in The Economics of Contracts. Eric Brousseau and Jean-Michel Glachant, eds. Cambridge: Cambridge University Press.

Majumdar, Sumon and Sharun Mukand. 2007. "The Leader as Catalyst: On Leadership and the Mechanics of Institutional Change,” Working Paper, Department of Economics, Queen's University.

McNulty, Paul J. 1984. "On the Nature and Theory of Economic Organization: The Role of The Firm Reconsidered," History of Political Economy 16: 233-253.

Malmgren, Harold B. 1961. "Information, Expectations, and the Theory of the Firm," Quarterly Journal of Economics 75: 399-421.

March, James G. and Herbert A. Simon. 1958. Organizations. New York: Wiley.

Marschak, Jacob and Roy Radner. 1972. The Theory of Teams. New Haven: Yale University Press.

Marschak, Thomas. 1965. "Economic Theories of Organization," in James G. March, ed. The Handbook of Organizations. Chicago: Rand McNally and Co.

Maskin, Eric and Jean Tirole. 1999. "Unforeseen Contingencies and Incomplete Contracts," Review of Economic Studies 66: 83-114.

Masten, Scott E. 1984. “The Organization of Production: Evidence from the Aerospace Industry,” Journal of Law and Economics 27: 403-417.

Masten, Scott E. 1988. “A Legal Basis for the Firm,” Journal of Law, Economics, \& Organization 4: 181-198

Ménard, Claude. 1996. "On Clusters, Hybrids and other Strange Forms.” Journal of Institutional and theoretical Economics 152: 154-183. 
Ménard, Claude. 2004. "The Economics of Hybrid Organizations." Journal of Institutional and Theoretical Economics 160: 345-376.

Ménard, Claude, and Peter G. Klein. 2004. "Organizational Issues in the Agri-Food Sector: Toward a Comparative Approach.” American Journal of Agricultural Economics 86: 750-755.

Meyer, J. W., and B. Rowan. 1977. "Institutionalized Organizations: Formal Structure as Myth and Ceremony;" American Journal of Sociology, 83: 340-363.

Milgrom, Paul J. and John D. Roberts 1996. Bargaining Costs, Influence Costs and the Organization of Economic Activity, in Putterman, J. and Kroszner, R. eds. The Economic Nature of the Firm, Cambridge, Cambridge University Press

Milgrom, Paul J. and John D. Roberts. 1988a. "An Economic Approach to Influence Activities in Organizations," American Journal of Sociology 94: S154-S179.

Milgrom, Paul J. and John D. Roberts. 1988b. "Economic Theories of the Firm: Past, Present, and Future," Canadian Journal of Economics 21: 444-458.

Miller, Gary. 1992. Managerial Dilemmas. Cambridge: Cambridge University Press.

Moe, Terry M. 1984. "The New Economics of Organization," American Journal of Political Science 28: 739-777

Moe, Terry M. 1990. "The Politics of Structural Choice: Toward a Theory of Public Bureaucracy," in Oliver E. Williamson, ed., Organization Theory, New York, Oxford University Press, pp. 116-153.

Moe, Timothy. 1997. A Positive Theory of Public Bureaucracy, in Mueller, D. C. ed. 1997. Perspectives in Public Choice: A Handbook, New York, Cambridge University Press

Mookerjee, Sujoy. 1998. "Ambiguity Aversion and Incompleteness of Contractual Form," American Economic Review 88: 1207-1231.

Nelson, Richard R. and Sidney G. Winter. 1973. "Toward an Evolutionary View of Economic Capabilities," American Economic Review 63: 440-449.

Nelson, Richard R. and Sidney G. Winter. 1982. An Evolutionary Theory of Economic Change. Cambridge, MA: The Belknap Press.

Nickerson, Jackson A. and Richard Vanden Bergh. 1999. "Economizing in a Context of Strategizing: Governance Mode Choice in Cournot Competition," Journal of Economic Behavior and Organization 40: 1-15.

Niskanen, William A. 1971. Bureaucracy and Representative Government. Chicago, AldineAtherton.

Nooteboom, Bart, and Frederique Six. 2003. The Trust Process in Organizations: Empirical Studies of the Determinants and the Process of Trust Development. Aldershot: Edward Elgar.

North Douglass C. and Barry R. Weingast. 1989. "Constitutions and Commitment: The Evolution of Institutional Governing Public Choice in Seventeenth-Century England," Journal of Economic History 49: 803-832.

Osterloh, Margit and Bruno Frey. 2000. "Motivation, Knowledge Transfer and Organizational Form," Org Sci, 11, pp. 538-550. 
Oxley, Joanne E. 1997. “Appropriability Hazards and Governance in Strategic Alliances: A Transaction Cost Approach.” Journal of Law, Economics, and Organization 13: 387-409.

Palay, Thomas M. 1984. "Comparative Institutional Economics: The Governance of Rail Freight Contracting.” Journal of Legal Studies 13: 265-287.

Palay, Thomas M. 1985. "Avoiding Regulatory Constraints: Contracting Safeguards and the Role of Informal Agreements.” Journal of Law, Economics, and Organization 1: 155-176.

Penrose, Edith T. 1959. The Theory of the Growth of the Firm. Oxford: Oxford University Press.

Perrow, Charles. 1986. Complex Organizations: A Critical Essay. Glenview, Ill.

Perrow, Charles. 2002. "Economic Theories of Organization," Central Currents in Organization Theory 4: 244-271.

Pfeffer, Jeffrey and Gerald Salancik. 1978. The External Control of Organizations: A Resource Dependence Perspective. New York, Harper \& Row.

Porter, Michael E. 2000. "Location, Competition, and Economic Development: Local Clusters in a Global Economy." Economic Development Quarterly 14: 15-34.

Putterman, Louis. 1986. The Economic Nature of the Firm: A Reader. Cambridge: Cambridge University Press.

Radner, R. 1968. “Competitive Equilibrium under Uncertainty,” Econometrica 36: 31-58.

Radner, Roy. 1996. "Bounded Rationality, Indeterminacy, and the Theory of the Firm," Economic Journal 106: 1360-1373.

Rajan, Raghuram G. and Luigi Zingales. 1998. "Power in a Theory of the Firm," Quarterly Journal of Economics 113: 387-432.

Rajan, Raghuram, and Julie Wulf. 2003. "The Flattening Firm: Evidence from Panel Data on the Changing Nature of Corporate Hierarchies.” NBER Working Paper No. 9633.

Ravenscraft, David J., and F. M. Scherer. 1987. Mergers, Sell-Offs, and Economic Efficiency. Washington, D.C.: Brookings Institution.

Richardson, George B. 1972. “The Organisation of Industry,” Economic Journal 82: 883-96.

Robinson, Joan. 1933/1969. The Economics of Imperfect Competition. 2nd ed. London: Macmillan.

Roethlisberger, Fritz J. and William J. Dickson. 1939. Management and the Worker. Cambridge, Mass.: Harvard University Press.

Ross, Stephen. 1973. “The Economic Theory of Agency: The Principal's Problem," American Economic Review 63: 134-139.

Rumelt, Richard P., Dan E. Schendel, and David J. Teece, eds. 1994. Fundamental Issues in Strategy, Boston: Harvard Business School Press.

Salanié, Bernard. 1997. The Economics of Contracts. Cambridge, Mass.: MIT Press.

Sanzhar, Sergey V. 2006. "Discounted But Not Diversified: Organizational Structure and Conglomerate Discount.” Working Paper, Kenan-Flagler School of Business, University of North Carolina. 
Saussier, Stephane. 2000. "Transaction Costs and Contractual Incompleteness: The Case of Electricitè de France," Journal of Economic Behavior and Organization 42: 189-206.

Scott, W. Richard. 1992. Organizations: Rational, Natural, and Open Systems. Englewood Cliffs: New Jersey.

Scott, W. Richard. 1995. Institutions and Organizations. London: Sage.

Scott, W. Richard. 2004. "Reflections on a Half-Century of Organizational Sociology," Annual Review of Sociology 30: 1-21.

Schütz, Alfred. 1964. Collected Papers II: Studies in Social Theory. The Hague: Martinus Nijhoff.

Segal, Ilya. 1999. "Complexity and Renegotiation: A Foundation for Incomplete Contracts," Review of Economic Studies 66: 57-82.

Selznick, Philip. 1957. Leadership in Administration: A Sociological Interpretation. New York: Harper \& Row.

Shelanski, Howard A., and Peter G. Klein. 1995. "Empirical Research in Transaction Cost Economics: A Review and Assessment." Journal of Law, Economics and Organization 11: 335361.

Shepsle, Kenneth A. and Barry R. Weingast. 1987. "The Institutional Foundations of Committee Power," American Political Science Review 81: 85-104.

Simon, Herbert A. 1951. "A Formal Theory of the Employment Relationship," Econometrica 19: 293-305.

Simon, Herbert A. 1955, “A Behavioral Model of Rational Choice," Quarterly Journal of Economics 69, pp. 99-118.

Simon, Herbert A. 1991. "Organizations and Markets," Journal of Economic Perspectives 5: 2544.

Starr, Ross. 2003. "Why Is There Money? Endogeneous Derivation of 'Money' as the Most Liquid Asset: A Class of Examples," Economic Theory 21.

Steer, P. and John Cable. 1978. "Internal Organization and Profit: An Empirical Analysis of Large U.K. Companies.” Journal of Industrial Economics 27: 13-29.

Sugden, Robert. 1991. "Rational Choice: A Survey of Contributions from Economics and Philosophy,” Economic Journal 101: 751-785.

Teece, David J. 1980. "Economies of Scope and the Scope of the Enterprise." Journal of Economic Behavior and Organization 1: 223-247.

Teece, David J. 1981. "Internal Organization and Economic Performance: An Empirical Analysis of the Profitability of Principal Firms." Journal of Industrial Economics 30: 173-199.

Teece, David J. 1982. "Towards an Economic Theory of the Multiproduct Firm," Journal of Economic Behavior and Organization 3: 39-63.

Tepper, B. J. and Taylor, E. C. 2003. Relationships among Supervisors and Subordinates, Procedural Justice Perceptions and Organizational Citizenship Behaviors, Academy of Management Journal, 46: 97-105 
Thompson, James D. 1967. Organizations in Action: Social Science Bases of Administrative Theory. New York: McGraw-Hill.

Thompson, R. S. 1981. "Internal Organization and Profit: A Note." Journal of Industrial Economics 30: 201-211.

Tirole, Jean. 1999. “Incomplete Contracts: Where Do We Stand?" Econometrica 67: 741-781.

Tullock, Gordon. 1967. "'The Welfare Costs of Tariffs, Monopolies and Theft," Western Economic Journal 5: 224-232.

Weber, Max. 1947. The Theory of Social and Economic Organization. New York: Free Press.

Weingast, Barry R. 1997. "The Political Foundations of Democracy and the Rule of Law," American Political Science Review 91: 245-263.

Weiss, Marco. 2007. Efficient Organizational Design: Balancing Incentives and Power. London: Macmillan.

Wernerfelt, Birger 1994. "An Efficiency Criterion for Marketing Design,” Journal of Marketing Research 31: 462-470.

Wernerfelt, Birger. 1997. "On the Nature and Scope of the Firm: An Adjustment Cost Theory," Journal of Business 70: 489-514.

Whinston, Michael D. 2001. "Assessing the Property Rights and Transaction-Cost Theories of Firm Scope.” American Economic Review 91: 184-188.

Williamson, Oliver E. 1964. The Economics of Discretionary Behavior: Managerial Objectives in a Theory of the Firm. Englewood Cliffs: Prentice-Hall.

Williamson, Oliver E. 1970. Corporate Control and Business Behavior. Englewood Cliffs: Prentice Hall.

Williamson, Oliver E. 1971. "The Vertical Integration of Production: Market Failure Considerations," American Economic Review 61: 112-123

Williamson, Oliver E. 1975. Markets and Hierarchies. New York: Free Press.

Williamson, Oliver E. 1976. "Franchise Bidding for Natural Monopolies-In General and with Respect to CATV." Bell Journal of Economics 7: 73-104.

Williamson, Oliver E. 1985. The Economic Institutions of Capitalism. New York: Free Press.

Williamson, Oliver E. 1991. "Strategizing, Economizing, and Economic Organization," Strategic Management Journal 12: 75-94.

Williamson, Oliver E. 1996. The Mechanisms of Governance. Oxford: Oxford University Press.

Williamson, Oliver E. 2000. "The New Institutional Economics: Taking Stock, Looking Ahead," Journal of Economic Literature 38: 595-613.

Williamson, Oliver E. 2002. "The Lens of Contract: Private Ordering," American Economic Review 92 (PaP): 438-443.

Williamson, Oliver E. and Scott Masten, eds. 1995. Transaction Cost Economics. Aldershot: Edward Elgar.

Winter, Sidney G. 1988. "On Coase, Competence, and the Corporation," in Oliver E. Williamson and Sidney G. Winter, eds. The Nature of the Firm. Oxford: Basil Blackwell. 
Witt, Ulrich. 1999. 'Do Entrepreneurs Need Firms? A Contribution to a Missing Chapter in Austrian Economics," Review of Austrian Economics 11: 99-110.

Zenger, Todd R. 1994. "Explaining Organizational Diseconomies of Scale in Research-andDevelopment: Agency Problems and the Allocation of Engineering Talent, Ideas, and Effort by Firm Size," Management Science 40: 708-729.

Zenger, Todd R. and William S. Hesterly. 1997. "The Disaggregation of Corporations: Selective Intervention, High-powered Incentives, and Molecular Units," Organization Science 8: 209-222 
Figure 1

\section{Game 1}

\begin{tabular}{ccc} 
& \multicolumn{2}{c}{ B } \\
& left & right \\
up & 2,2 & 0,0
\end{tabular}

A

down $\quad 0,0$

\section{Game 2}

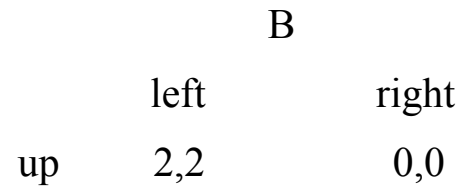

A

down $\quad 0,0 \quad 4-\mathrm{u}, 1+\mathrm{u}$


Table 1: Streams of research in organizational economics

\begin{tabular}{|c|c|c|c|c|c|}
\hline & $\begin{array}{l}\text { Conceptualiza- } \\
\text { tion of the firm }\end{array}$ & Rationality & Contracting & $\begin{array}{c}\text { Organizational } \\
\text { Governance }\end{array}$ & $\begin{array}{c}\text { Transaction costs } \\
\text { considered }\end{array}$ \\
\hline Nexus of contracts & A legal fiction & Maximizing & Complete & $\begin{array}{l}\text { The reality of au- } \\
\text { thority is denied. No } \\
\text { substantive differ- } \\
\text { ence between market } \\
\text { governance and } \\
\text { organizational go- } \\
\text { vernance. Input } \\
\text { monitoring domi- } \\
\text { nates in organiza- } \\
\text { tions; output moni- } \\
\text { toring in markets. }\end{array}$ & $\begin{array}{l}\text { Ex post TC, e.g. } \\
\text { monitoring and } \\
\text { bonding costs }\end{array}$ \\
\hline $\begin{array}{l}\text { Formal princi- } \\
\text { pal/agent theory }\end{array}$ & $\begin{array}{l}\text { No distinct con- } \\
\text { ceptualization }\end{array}$ & Maximizing & Complete & $\begin{array}{l}\text { Insights in informa- } \\
\text { tiveness principle, } \\
\text { incentive internsity, } \\
\text { multi-tasking, etc.; } \\
\text { however, these are } \\
\text { are not particular to } \\
\text { organizations. }\end{array}$ & Costs of monitoring \\
\hline $\begin{array}{l}\text { Incompl. contracts: } \\
\text { coordination }\end{array}$ & $\begin{array}{l}\text { An authority re- } \\
\text { lation }\end{array}$ & Mostly bounded & Incomplete & $\begin{array}{l}\text { Authority is the } \\
\text { defining characteris- } \\
\text { tic of the firm. }\end{array}$ & $\begin{array}{l}\text { Haggling and com- } \\
\text { munication costs }\end{array}$ \\
\hline $\begin{array}{l}\text { Incompl. contracts: } \\
\text { asset spec. and } \\
\text { prop. rights }\end{array}$ & $\begin{array}{l}\text { A collection of resi- } \\
\text { dual decision rights } \\
\text { to physical assets }\end{array}$ & $\begin{array}{l}\text { Williamson: } \\
\text { bounded } \\
\text { Hart: maximizing }\end{array}$ & Incomplete & $\begin{array}{l}\text { Ownership rights to } \\
\text { alienable assets } \\
\text { confer authority } \\
\text { (Hart). Authority } \\
\text { and hierarchy is a } \\
\text { private ordering } \\
\text { (Williamson). }\end{array}$ & $\begin{array}{l}\text { Costs of drafting } \\
\text { complex contracts }\end{array}$ \\
\hline
\end{tabular}

